\title{
LA- -9039
}

DE82 015079

\section{Nuclear Power in the Soviet Bloc}

\author{
William G. Davey
}

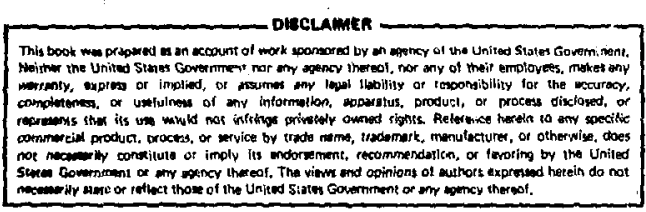

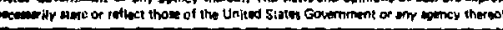

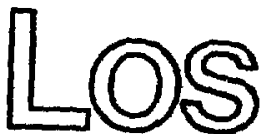

Alamos 


\section{CONTENTS}

ABSTRACT

I. INTRODUCTION THE SOVIET COMMITMENT TO NUCLEAR POWER

II. HISTORICAL OVERVIEW .................... 3

A. USSR Domestic Program .............. 3

B. USSR and comecon ................. 4

C. USSR and Non-Comecon Countries ............. 5

III. METHODOLOGY OF PROJECTIONS OF SOVIET BLOC NUCLEAR ENERGY $\ldots \ldots$. . 5

IV. CURRENT AND PROJECTEO NUCLEAR ENERGY PROGRAMS . . . . . . . 7

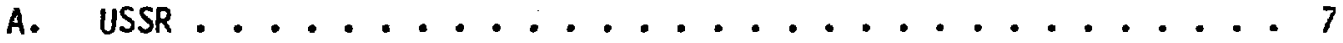

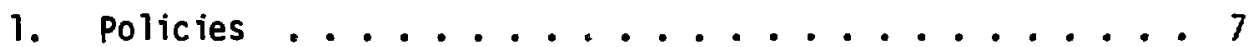

2. Operating Reactors and construction to 1985 ..... 8 a. LGR Development and Instailation........ 9

b. PWR Development and Installation ........ 9

c. Unknown Reactor Types ............ 10

d. Total Capacity Through $1985 \ldots . . . . . .12$

3. Projected Capacity to 2000 ........... 12

a. Official Projections ............ 13

b. Technical Projections .......... 14

c. Overall Projections to $2000 \ldots 16$

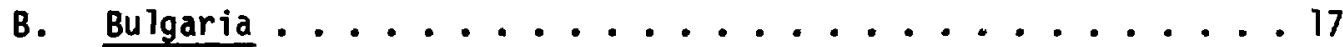

1. Energy Overview and Nuclear Policy ......... 17

2. Operating Reactors and Construction to 1985 ..... 17

3. Projected capácity to 2000 ............ 18

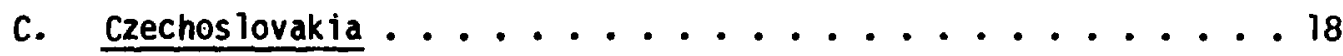

1. Energy Overview and Nuc lear Policy ......... 18

2. Nuclear Activities in Czechoslovakia .........19

3. Operating Reactors and Construction to 1985 ......20

4. Construction beyond $1985 \ldots . . \ldots 1$

5. Projected Capacity to 2000 ............ 22 
D. German Democratic Republic (GDR) ........... 23

1. Energy Overview and Nuclear Policy ......... 23

2. Operating Reactors and Construction ......... 24

3. Projection to $2000 \ldots . . . . . . . . . .25$

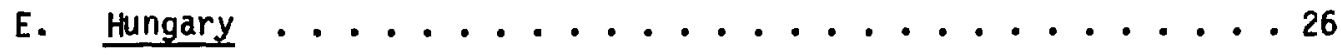

1. Energy Overview and Nuclear Policy .......... 26

2. Reactors under construction ........... 26

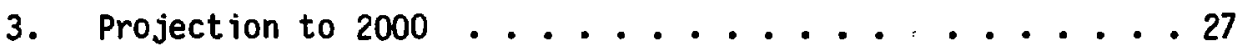

F. Poland ..................... 27

1. Energy Overview and Nuclear Policy ......... 27

2. Reactors under construction ........... 28

3. Projection to $2000 \ldots \ldots 28$

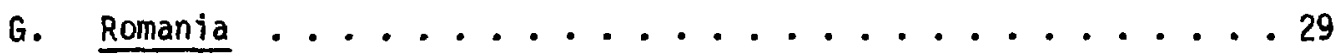

1. Energy Overview and Nuclear Policy ......... 29

2. Reactors Under construction ............ 29

3. Projection to $2000 \ldots 30$

v. SUMMARY OF SOVIET BLOC PROJECTIONS TO $2000 \ldots 30$

APPENDIX. DETAILS OF SOVIET BLOC NUCLEAR POWER . . . . . . . . 34 
NUCLEAR POWER IN THE SOVIET BLOC

by

W. G. Davey

\begin{abstract}
The growth of Soviet Bloc nuclear power generation to the end of the century is evaluated on the basis of policy statements of objectives, past and current nuclear power plant construction, and trends in the potential for future construction. Central to this study is a detailed examination of individual reactor construction and site development that provides specific performance data not given elsewhere. A major commitment to nuclear power is abundantly clear and an expansion of ten times in nuclear electric generation is estimated between 1980 and 2000 . This rate of growth is likely to have significant impact upon the total energy economy of the Soviet Bloc including lessening Cemands for use of coal, oil, and gas for electricity generation.
\end{abstract}

1. INTRODUCTION: THE SOVIET COMMITMENT TO NUCLEAR POWER

A)though nuclear electric plants in the USSR date from the late' 50 s when the Troitsk reactors were built, it was only during the 170 s that a significant industrial effort developed. This dates from the completion of the first 440-Me standardized Pressurized Water Reactor (PWR) at Novovoronezh in 1972 and the first 1000-MWe Light-water-cooled Graphite Reactor (LGR) at Leningrad in 1974. As a consequence, although the USSR and the other Communist nations of Eastern Europe officially supported the widespread use of nuclear power from its inception, only in the past 5 to 10 years have their plans begun to bear fruit and consequently, made possible a more realistic assessment of this source of energy. 
The interit is clear. Nuclear power will be used on a large scale throughout the Soviet Bloc to generate electricity and on some as-yet-undefined scale for space heating of cities and industrial enterprises. The reactor safety, environmental, and nuclear weapons concerns so evident in the Western World play no role in Soviet Bloc planning. Nuclear plants not only have no separate containment structure ${ }^{*}$ (as in 211 Western reactors) but are situated where needed and not, for example, remote from cities. Constraints will be only such factors as the required rate of increase of electricity production, the feasible rate of construction of nuclear plants, and the depletion (or uneconomic nature) of alternative sources of energy. This last point is of particular importance because (1) the sources of coal, oil, and gas in the western part of the USSR are decreasing (as they are in Eastern Europe), and (2) the new large energy reserves are located in Siberia, 3000 to $5000 \mathrm{~km}$ from the major industry and population centers, which are principally west of the Ural Mountains,

Nuclear fuel, being such a concentrated energy source, is easily transported at relatively low cost. Where distances are great and climate harsh, it therefore becomes very attractive.

In Eastern Europe, the climatic incentive for use of nuclear power is clearly. less than in the USSR, but the transportation problem is shared because much of the energy is obtained from the USSR. In addition, all Eastern European countries have incentives for reduced dependence upon external energy supplies from the USSR or elsewhere. Nuclear power is thus desirable since some countries have significant uranium resources. Although the USSR is unlikely to agree with all aspects of their national viewpoints, it supports vigorous nuclear programs in this area through the eleven-nation Council for Mutual Economic Assistance (CMEA, CEMA, or Comecon). These efforts involve partitioning industrial development into specialized components, as well as joint financing of cooperative projects.

The details for each country are given later but the overall pattern is clear: nuclear power will be a major factor in Soviet. Bloc energy supply by the end of this century.

*Recent information (1982) indicates that containment is now being provided for Soviet reactors. 
As in the US, Britain, and France the USSR nuclear energy program evolved from a nuclear weapons program. The nuclear energy programs in the other comecon* countries are mostly extensions of the USSR's.

\section{A. USSR Domestic Program}

In the US, Britain, and France, nuclear weapons manufacture involved the construction of natural uranium-fueled graphite-moderated thermal reactors for plutonium production and diffusion or centrifuge plants for uranium enrichment. British and French reactors were gas cooled and used extensively for joint production of electricity and plutonium. US reactor's were water cooled and used to a lesser extent for that dual purpose. The PWR, which requires enriched uranium and can be compact, was developed for nuclear-powered submarines in the US (also later in Britain and France), and this led to the development of commercial PWRs for electricity production.

Discerning the common pattern in the nuclear weapon activities of these three states is very instructive, since we can assume that the USSR followed a generally similar pattern. Thus we understand nuclear energy development in the USSR even though little is known about the infrastructure of mining, milling, enrichment, reprocessing, etc. We could identify the graphite-moderated reactors located at the remote sites of Troitsk and Beloyarsk as the jointpurpose forerunners of the series of large electricity-generating plants started at Leningrad in 1974. These LGRs differ from basically similar systems in Britain and France in that cooled water is allowed to boil and the fuel is enriched uranium. Similarly, the earlier smaller PWRs developed at Movovoronezh in the early ' 60 s possibly were related to naval reactors and were the basis $f$ ' developing the standard 440-MWe Novovoronezh (VVER 440) and 1000-me (VVER 1000) PARs now being constructed in the USSR and elsewhere. Possibly the USSR discovered, as did Britain and France, that PWR stations are more convenient, or more economical, or better suited for large-scale

*The Council for Mutual Economic Assistance (abbreviated as CMEA, CEMA, or Comecon) was established in January 1949 in response to the Marshall Plan. Today (1981) it has ten members: the Soviet Union, Bulgaria, Czechosiovakia, East Germany, Hungary, Poland, Romania, Cuba, Mongolia, and Vietnam. 
manufacture than graphite-moderated reactors. PWRs may displace LGRs in the future USSR building program.

Another aspect of the USSR program that parallels the other countries' is the development of the plutonium-fueled, Liquid Metal Fast Breeder Reactor (LMFBR), which uses essentially all the energy in uranium rather than the few percent released in thermal reactors. This could lead to about a twenty-fold increase in the energy available from uranium ores when they are significantiy depleted, perhaps in the late '90s or the early decades of the next century. The research programs, basic reactor designs, and approximate time scale for LMFBRs are closely similar in the USSR, Britain, France, and Japan.

The PWR, LGR, and LMFBR reactors form the basis of the USSR nuclear electric program, but an additional feature that is emerging is the use of nuclear energy for space heating. Since 1974, nuclear power has been used on a small scale to provide both heat and eiectricity to the small remote town of Bilibino in the extreme northeast (almost on the Arctic coast). Now large stations are being built for major cities in the western USSR. Space heating probably will utilize both "waste heat" from electricity generation and special reactors for this purpose.

\section{B. USSR and Comecon}

With the exception of an abortive early development by Czechoslovakia and prolonged interchange between Rumania and Canada, the Comecon nuclear programs are extensions of USSR technology, and key elements are held under close USSR control. Although several countries, particularly Czechoslovakia, mine uranium, it is controlled either by USSR companies or jointly held companies dominated by the USSR. There is no evidence of fuel element manufacture outside the USSR, and all fuel is supplied from the USSR and returned there for reprocessing or storage after use in the reactors. With minor exceptions, discussed later, all reactors are PWRs, and the essential enrichment of the uranium required for these reactors can be carried out only in the USSR.

This is perhaps, in part, a logical corollary of the agreement for specialized manufacture of certain items that is in effect among the comscon countries; for example, Czechoslovakia now manufactures VVER-440 PWRs for all comecon countries. Nevertheless, this arrangement certainly minimizes weapons-proliferation potential of nuclear power in the comecon countries. 
Intra-Comecon cooperation is also demonstrated in the joint funding of nuclear power stations by several countries. To date, this cooperation only exists for constructing a station in the USSR with repayment of the non-USSR contribution (over a limited period) by export of electricity to these countries, so this facet of nuclear power is also biased strongly to the advantage of the USSR.

C. USSR and Non-Comecon Countries

When appropriate, the USSR is firmly involved in activities outside the Soviet Bloc.

To date (late 1981), the only export of USSR reactors has been to Finland where two VVER-440 PWRS are in operation, modified by adding containment vessels requested by Finland. As with Comecon countries, all fuel supplied by the USSR must be returned to the USSR for reprocessing. Reactors for cuba, Libya, and possibly Turkey have been discussed, and undoubtedly the same conditions for return of their fuel would be imposed.

Finland, and particularly Yugoslavia, manufacture reactor components for the Comecon countries (including the USSR). Yugoslavia, although not a member of Comecon, is in many ways part of the overall comecon manufacturing complex, and Firland and the USSR have discussed joint manufacture of reactors (for Libya) and of a USSR nuclear icebreaker.

One area where the USSR is strongly involved in international nuclear power is enrichment. In recent years, the USSR has provided about half the enrichment services for Western Europe at competitive prices. The enriched uranium is supplied to the USSR by the customer and does not come from Soviet Bloc resources.

III. METHODOLOGY OF PROJECTIONS FOR SOVIET BLOC NUCLEAR ENERGY

Determining the current status of Soviet Bloc industry can be an uncertain and frustrating task as information frequently is not available and usually incomplete. For nuclear energy, there are additional complications because some aspects of its peaceful uses are related to military applications and therefore information is classified. As a consequence, little or nothing is known about uranium mining, refining, enrichment, reprocessing, and waste 
handling, and a reasonably complete overall view of the Soviet nuclear energy industry is impossible to obtain.

Anticipated construcion in most major areas is given in the USSR FiveYear Plans. In the USSR and other Comecon countries; high-level pronouncements occasionally are made about long-term plans, but these statements must be considered with care. The Five-Year Plans and other official statements have been optimistic in the past, so it is wise to take these statements as targets or upper limits to what will be achieved. They do, however, indicate the government's intent, and in many cases the planned levels likely will be achieved, but at some later date. These statements also tend to be couched in broad terms and may refer to percentage increases from some base level that may be unclear. Thus we see that official statements have some value but it is limited.

Our method is basically to extrapolate from past experience in nuclear power plant construction but also to include probable technical changes in the industry. The official pronouncements are used as a guide to the government's intent and as an upper limit that probably will be achieved but at a later date than planned.

Specifically, we use the following methodology

- Note the anticipated power level, construction starting date; and actual operating date of each reactor identified in the Soviet statements.

- Al low for such technical evolution as increase in reactor size, standardization and factory manufacture of reactors, and changes in the reactor mix as time proceeds.

- Note each site identified by name and estimate its probable capacity and operating date.

- Use official statements of future plans as upper limits, which indicate the approximate magnitude of the rate of expansion.

This approach does not allow for any significant changes in limitations to production rates. For example, the premise that there is a sufficient uranium supply and enrichment capacity for the current Five-Year Plan (198185) also is assumed to apply to the year 2000. This is probably reasonable up to the year 2000, and possibly beyond, but it is impossible to be confident that these projections will remain valid because of unknown snags or other limitations. 
This section discusses the nuclear program of each comecon country and est imates the nuclear energy capacity to the year 2000 . First we consider the USSR because of its central role and then the rest of the comecon countries (in alphabetical order).

Much of the information available consists of isolated details that are significant only in evaluating the progress of a specific plant. As far as possible we confine detailed discussions to the Appendix, together with references to the sources. The Appendix contains all the specifics upon which this study was based. In the main text we include the policies adopted by each country and some background to help understand how the individual programs developed. Finally, we sumarize the actual growth of and projections for nuclear electric-plant construction.

A. USSR

1. Policies. The USSR's commitment to a strong and expanding domestic role for nuclcar power has been stated repeatedly at the highest levels. The increased electrification that will be necessary, because of increasing gas and oil transportation costs, was stated clearly by Academician Styriovich (June 1980) together with the unequivocal statement that "atomic power stations generate electric power at a substantially lower cost than other power stations do" with minor qualifications for a few mine-mouth coal-powered stations. 1 The President of the USSR ACademy of Sciences confirmed and extended this conviction by stating that "the entire deficit in the fuel and power balance should be covered... by a substantial expansion of the share of atomic power engineering" and noting that "atomic heat supply stations" for cities will be realized in the 1981-85 Five-Year Plan. ${ }^{2}$

These statements were confirmed by Brezhnev himself in the Draft Guidelines for the 11th Five-Year Plan $(1981-85),{ }^{3}$ which details construction of nuclear electric plants throughout the western USSR as well as "atomic reactors for supplying heat to large cities." ${ }^{3}$ Further details on these plants are given in the Major Construction Projects for 1981. 4

The incentives are clear: (1) decreasing availability of energy sources -. coal, oil, gas, and hydro .. in the western USSR where most industry is 
located; (2) difficulty and considerable cost in developing remote sources in generally inhospitable regions; and (3) accelerating transportation costs. The export of oil and other energy resources constitutes an important source of hard currency vital to the USSR for import of industrial goods and wheat. Greater internal use of other energy sources then will assist in maintaining and perhaps increasing these exports.

The USSR has strong incentives to maintain control of the key fuel supply and reprocessing areas in the other comecon countries. A major reason is probably to minimize nuclear weapon proifferation risks; the experience with nuclear aid to china, followed by antagonism and independent weapons development, must have been sobering. ${ }^{5}$ In addition, control over fuel supplies gives great political leverage and is also profitable. The USSR also has strong economic incentives to encourage increased nuclear energy use in the Comecon countries, thus reducing their dependence on nonnuclear fue 1 supplied from the USSR. For example, the USSR would certainly benefit by selling its oil at world market prices instead of, as now, supplying it well below this level.

Regarding the rest of the world, the USSR can be expected to export reactors, particularly to its sympathizers, under the same terms of fuel supply and return after irradiation that it now requires. Such an arrangement applies to USSR reactors in Finland. Libya and Cuba will receive reactors but iime scales and other details are lacking; exports to Turkey and Yugoslavia also have been indicated as a possibility.

The USSR can be expected to continue enrichment services on the open market on a commercial basis, unless and until these services are needed exclusively for itself and its allies.

2. Operating Reactors and Construction to 1985. The Appendix gives details of each USSR site and reactor in the chronological order of first operation or announcement of construction. All sources and significant items of construction and operation are given as well as the type of information from which projections must be constructed.

The Appendix should be read to obtain an appreciation of the difficulties, successes, breadth, and objectives of the USSR program. For example: some of the construction difficulties found in the Chernobyl station are given; the Nikolayev site is part of a nuclear/hydroelectric/pumped storage 
complex; Khmelnitsky is to be constructed jointly by the USSR, Poland, Hungary, and Czechoslovakia; and reactors to be specially constructed in Odessa and Gorki are for district heating of those cities.

In this section we summarize the information on electricity production given in the Appendix, grouped into LGRS, PWRs, and reactors of unknown designation.

Neither the Appendix nor this section considers experimental reactors nor the future use of LMFBRs. Fast reactors probably will be introduced into regular operation in the 1990s but we assume that they will not make a significant impact until after 2000. Because too little information is available, we made no estimate of the contribution to the total energy economy of the district-heating reactors nor of their contribution to electricity production if they are dual purpose. Nevertheless, this source of energy (electricity and heat) could be significant by 2000 .

a. LGR Development and Installation

The start-up dates, capacity installed per year, and cumulative capacity are shown in Table I. The reactors are grouped into three categories.

- Early developmental types (Troitsk, Beloyarsk)

- Standard 1000 MWe (Leningrad, Kursk, Chernobyl, Smolensk)

- Advanced 1500 MWe (Ignalina)

Commercial development began in 1974 with the first Leningrad reactor, and the introduction of Ignalina 1 in 1983 probably will represent the beginning of a new period when the "standard size" will have increased to 1500 MWe. We can expect a number of 1000-MWe LGRs to be put into service beyond 1983 (as indicated) to complete those currently under construction, but beyond 1985 probably most or all LGRs will be 1500 MWe and the station capacity will be 6000 MWe rather than 4000 MWe.

b. PWR Development and Installation

The relevant data are given in Table II. Novovoronezh is the development site, and the first VVER-440 and YVER-1000 units were built there as well as the earlier smaller systems.

It is probable that most reactors built after 1980 will be the larger second-generation VVER 1000. A few VVER-440 units will be built except where 


\section{TABLE 1}

\section{LIGHT-WATER-COOLED GRAPHITE REACTORS}

\begin{tabular}{|c|c|c|c|c|c|}
\hline \multirow[b]{2}{*}{$\begin{array}{l}\text { Year of } \\
\text { Start-Up }\end{array}$} & \multicolumn{3}{|c|}{ Category of Reactor } & \multicolumn{2}{|c|}{ Capacity } \\
\hline & Deve lopmental & $\begin{array}{l}\text { Standard } \\
1000 \text { MNe }\end{array}$ & $\begin{array}{l}\text { Advanced } \\
1500 \text { MHe }\end{array}$ & $\begin{array}{l}\text { Added } \\
\text { (Mive) }\end{array}$ & $\begin{array}{c}\text { Cumulative } \\
\text { (MNe) }\end{array}$ \\
\hline 1958 & Troitsk $1-6$ & & & 600 & 600 \\
\hline 1964 & Be \}oyarsk 1 & & & 100 & 700 \\
\hline 1967 & Beloyarsk 2 & & & 200 & 900 \\
\hline 1974 & & Leningrad 1 & & 1000 & 1900 \\
\hline 1975 & & Leningrad 2 & & 1000 & 2900 \\
\hline 1976 & & Kursk 1 & & 1000 & 3900 \\
\hline 1978 & & Chernobyl 1 & & 1000 & 4900 \\
\hline 1979 & & Kursk 2 & & 2000 & 6900 \\
\hline & & Chernobyl 2 & & & \\
\hline 1980 & & Chernobyl 3 & r & 2000 & 8900 \\
\hline & & Leningrad 3 & & & \\
\hline 1981 & & Kursk 3 & & 2000 & 10900 \\
\hline & & Leningrad 4 & & & \\
\hline 1982 & & Smolensk 1 & & 1000 & 11900 \\
\hline 1983 & & & Ignalina 1 & 1500 & 13400 \\
\hline 1984 & & $\begin{array}{l}\text { Kursk } 4 \\
\text { Chernobyl } 4\end{array}$ & & 2000 & 15400 \\
\hline 1985 & & Smo lensk 2 & Ignalina 2 & 2500 & 17900 \\
\hline
\end{tabular}

smaller capacity stations are needed (such as remote sites or small industrial/urban areas). Introduction of a large third-generation unit is less likely (than with the LGR) because the PWR tends to be factory built and not constructed on site. Consequently, there is more incentive to stay with a standardized unit. Additionally, transportation problems (of the pressure vessel) may impose size limitations. ${ }^{13}$

c. Unknown Reactor Types

Table III gives data for the Khmelnitsky 1 and 2 and Balakovo 1 and 2 reactors where the type is not known. Also, the year of start-up, 1985, is 
TABLE II

PRESSURIZED-WATER REACTORS

\begin{tabular}{|c|c|c|c|c|c|}
\hline \multirow{2}{*}{$\begin{array}{l}\text { Year of } \\
\text { Start-Up }\end{array}$} & \multicolumn{3}{|c|}{ Category of Reactor } & \multicolumn{2}{|c|}{ Capacity } \\
\hline & Deve lopmental & VVER -440 & WVER-1000 & $\begin{array}{l}\text { Added } \\
\text { (MWe) }\end{array}$ & $\begin{array}{l}\text { (Mue) } \\
\text { (Mulue }\end{array}$ \\
\hline 1964 & Novovoronezh 1 & & & 210 & 210 \\
\hline 1969 & Novovoronezh 2 & & & 365 & 575 \\
\hline 1972 & & Novovoronezh 3 & & 440 & 1015 \\
\hline 1973 & & Kola 1 & & 880 & 1895 \\
\hline & & Novovoronezh 4 & & & \\
\hline 1974 & & Kola 2 & & 440 & 2335 \\
\hline 1976 & & Armenia 1 & & 440 & 2775 \\
\hline 1980 & & Rovnio 1 & Novovoronezh 5 & 2760 & 5535 \\
\hline & & Armenia 2 & & & \\
\hline & & Kola 3 & & & \\
\hline & & Kola 4 & & & \\
\hline 1981 & & & Kalinin 1 & 1000 & 6535 \\
\hline 1982 & & & Nikolayev 1 & 1000 & 7535 \\
\hline 1983 & & & & & \\
\hline 1984 & & Rovno 2 & Kalinin 2 & 1440 & 8975 \\
\hline 1985 & & & Rouno 3 & 2000 & 10975 \\
\hline & & Nikolayev 2 & & & \\
\hline
\end{tabular}

TABLE III

REACTOR TYPE UNKNOWN

Approximate

Year of

Start-up

1985

1985
Reactor

Khmelnitsky 1 and 2

Balakovo 1 and 2

\begin{tabular}{cc}
\multicolumn{2}{c}{ Capacity } \\
\hline $\begin{array}{c}\text { Added } \\
\text { (MWe) }\end{array}$ & $\begin{array}{c}\text { Cumulative } \\
\text { (MWe) }\end{array}$ \\
\hline 4000 & 4000
\end{tabular}


TABLE IV

CAPACITY ADOED PER YEAR AND CUMULATIVE CAPACITY - REACTORS OF ALL TYPES

\begin{tabular}{|c|c|c|c|c|c|}
\hline \multirow[b]{2}{*}{ Year } & \multicolumn{2}{|c|}{ Capacity } & \multirow[b]{2}{*}{ Year } & \multicolumn{2}{|c|}{ Capacity } \\
\hline & $\begin{array}{l}\text { Added } \\
\text { Per Year } \\
\text { (MWe) } \\
\end{array}$ & $\begin{array}{c}\text { Cumulat ive } \\
\text { (MWe) }\end{array}$ & & $\begin{array}{l}\text { Added } \\
\text { Per Year } \\
\text { (MWe) }\end{array}$ & $\begin{array}{c}\text { Cumulat ive } \\
\text { (MWe) }\end{array}$ \\
\hline 1958 & 600 & 600 & 1976 & 1440 & 6675 \\
\hline 1964 & 310 & 910 & 1977 & -- & 6675 \\
\hline 1967 & 200 & 1110 & 1978 & 1000 & 7675 \\
\hline 1969 & 365 & 1475 & 1979 & 2000 & 9675 \\
\hline 1970 & -- & 1475 & 1980 & $4760^{a}$ & 14435 \\
\hline 1971 & -- & 1475 & 1981 & 3000 & 17435 \\
\hline 1972 & 440 & 1915 & 1982 & 2000 & 19435 \\
\hline 1973 & 880 & 2795 & 1983 & 1500 & 20935 \\
\hline 1974 & 1440 & 4235 & 1984 & 3440 & 24375 \\
\hline 1975 & 1000 & 5235 & 1985 & $8500^{a}$ & 32875 \\
\hline
\end{tabular}

The added capacities for 1980 and 1985 are probably artificially high and reflect a supposition that reactors will be finished in the 1976-80 and 1981-85 periods rather than that they are actually finished in 1985.

the last in the current Five-Year Plan period. No other info:mation is available.

\section{d. Total Capacity Through 1985}

Table IV gives the capacity added per year and cumlative capacity up to 1985 by adding the data given in Tables I through III. As noted in Table IV, the actual capacities added at the end of the plan period in 1985 are perhaps artificially high. Construction through 1981-85 is likely to be more uniformly distributed in time.

3. Projected Capacity to 2000. The methodology is discussed in Section III. Here we briefiv reiterate the principal guidelines and indicate why projections are not given beyond 2000 .

In projecting the generating capacity, we considered official statements of intent as indicators but tried to rely upon the extrapolation of past 
performance whenever feasible. This extrapolation takes account of technical advances that may be expected in future years so is not a simple projection of past experience. In addition, we relied upon statements of Soviet intent to build or complete a specific reactor station rather than generalizing statements.

In the late 1990s we may expect significantly increased introduction of the plutonium-fueled LMFBRs. The reasors will be mixed but will surely include concerns about depletion of uranium ores. If these supplies are indeed diminishing, there will be pressure to curtail building reactors that use enriched uranium (PWRs and LGRs) substituting instead LMFBRs. The size of uranium deposits is unknown so this variable makes projection beyond about 2000 quite uncertain; thus we do not extrapolate beyond this date. The LMFBR likely will have no major impact before 2000 . It requires a significantly different infrastructure and time to resolve technical problems, so our projections do not include this system.

A further point to note is that the use of speciai purpose reactors for space and industrial process heat probably will be widespread in the next twenty years. Our nuclear electric projections do not include these reactors although "waste heat" from electricity generation certainly will be used (possibly on a major scale).

\section{a. Official Projections}

The most realistic projections to 1985 should be based on both the off $i$ cial 1981-85 Five-Year Plan Guidelines ${ }^{3}$ and statements on Major Construction Projects for 1981. ${ }^{4}$ The plan calls for 1.55- to 1.60-trillion kilowatthours (kWh) to be generated in 1985, which is only $20 \%$ greater than the 1.335-trillion kWh in 1981. This relatively modest projection however is accompanied by the planned commissioning of 24000 to 25000 MW of new nuclear-electric capacity. Of the overall 1.55- to 1.60-trillion kWh to be generated, 220- to 225-billion $\mathrm{kWh}$ are intended to be nuclear (14\%) and 230to 235-billion kWh (15\%) hydroelectric.

Long-term projections can be grandiose. For example, in 1980 a senior engineer of Glavniiproekt, the main research and planning institute of the Ministry of Power and Electrification, stated that 13000 to $13500 \mathrm{MW}$ of nuclear power capacity would be on-line by the end of 1980, double that by the end of the 1981-85 plan, 100000 MW by 1990, and perhaps twice that amount, 
$200000 \mathrm{MW}$, by $2000 .^{6}$ Although the 1980 figure is reasonable, it should be noted that earlier projections for 1980 gave much higher figures and that these projections were gradually reduced as the plan progressed. Further, the 13000 to be constructed in 1981-85 is only about half the 24000 to 25000 given in the Five-Year $P 1$ an, and construction in the next Plan Period, 198690, is much higher at about 75000 MW. Accepting these statements as approximates seems more reasonable, particularly since a capacity of $100000 \mathrm{MW}$ is likely to be achieved sometime in the 1990s rather than in the year 1990. The figures were reported in an interview so it is quite possible that some of this confusion is due to misinterpretation of verbal statements.

\section{b. Technical Projections}

Projection of Past Experience. The installed capacity up to 1980 and projected to 1985 is summarized in Table IV. All of the data given here are based upon the actual or estimated start-up date of individual reactors at identified sites and can be considered to be quite irim.

Key points to be noted from these data follow.

- The figure of 14435 MWe for 1980 is reasonably consistent with 13000 to 13500 MWe quoted by Soviet officials (IV.A.3.a.).

- The added capacity through 1981-85 of 18440 MWe is not inconsistent with the Five-Yeur-Plan figure of 24000 to $25000 \mathrm{MWe}$, bearing in mind that this is likely to be optimistic.

- The capacities added in Five-Year-Plan periods are

$\begin{array}{rr}1971-75 & 3760 \text { MWe } \\ 1976-80 & 9200 \text { MWe } \\ 1981-85 & 18440 \text { MWe }\end{array}$

Thus, over this period of 15 years, the installed capacity per 5 years has roughly doubled in successive periods.

This accelerating rate of installation has been achieved by increasing both the number of reactors and their size. Although certainty about an increase in the number of reactors is impossible, we can expect the increasing size trend to continue. Both 440- and 1000-MWe PWRs will be constructed in the 1980-85 period (see Table II), but probably few, if any, of the smaller units will be built after 1985. Similarly, both 1000- and 1500-MWe LGRs will be luilt after 1983 (see Table I) but the trend will be towards the large size. For both reactor types there are "economies of scale," which means that 
the cost does not increase as rapidly as the output, and for the PWR there is the additional incentive of being able to construct VWER-1000 units in the new Atomash plant (see below).

At present, and through 1985, the installed capacity of LGRs is roughly double that of PWRs (Tables"I \& II), but probably the USSR will find, as did Britain and France, that PWRs are more economical. Thus, there probably will be a tapering off of LGR construction in favor of PWRs. The size increase is about $2.25(1000 / 440)$ for PWRs and $1.5(1500 / 1000)$ for LGKs, and there seems to be no reason why even larger LGRs could not be built. If more PWRs are built, we might then expect the average reactor size to double.

On this basis we infer that the rate of installation in the period 198690 might be twice that of the previous period and be in the range of 35000 to 40000 MWe. It is difficult to see this trend continuing beyond 1990, and there actually may be few or no LGRs constructed after that time.

PWR Construction at the Atommash Plant. This plant, alluded to previous ly, is under construction at Volgodonsk and is intended to mass produce VVER-1000 units. The first reactor will be completed in 1981 or $182 ; 7,8$ the "first stage" capacity should be three per year; and the final capacity is stated to be eight per year. ${ }^{8,9}$ When these levels of production will be achieved is not clear. Stated production capacities are likely to be optimistic, like all official projections, but a production rise to about two to three per year in 1985 and seven to eight per year in 1990 does not seem unreasonable.

Thus, for PWRs alone, the Atommash plant will be able to produce reactors at a rate of 35000 to 40000 Mwe per five-year period by 1990. If the argument on phasing out LGRs is correct, then this may indeed occur as the Atommash plant capacity rises to its final value. This is then consistent with an installation rate of LGRs and PWRs of 35000 to 40000 MWe through 1986-90 and of PWRs alone at the same rate beyond 1990, until LMFBRs begin to have major impact.

Completion of Identified Sites. Several individual sites might contain only two reactors for 1985 . But all sites probably will be expanded eventually to four reactors, which would add 2000 or 3000 MHe, depending upon whether two 1000-MHe PWRs or LGRs or two 1500-MWe LGRs are added. These sites might be completed in the 1986-90 period.

The following statistics are given for the uncompleted sites. 


\begin{tabular}{|c|c|c|c|}
\hline $\begin{array}{l}\text { Reactor } \\
\text { Site } \\
\end{array}$ & $\begin{array}{l}\text { Reactor } \\
\text { Type } \\
\end{array}$ & $\begin{array}{l}\text { Reactor } \\
\text { Capacity } \\
\text { (MWe) } \\
\end{array}$ & $\begin{array}{c}\text { Total Added } \\
\text { Capacity } \\
\text { (MWe) }\end{array}$ \\
\hline Rovno & (PWR) & $2 \times 1000$ & 2.000 \\
\hline Nikolayev & (PWR) & $2 \times 1000$ & 2000 \\
\hline Kalinin & (PWR) & $2 \times 1000$ & 2000 \\
\hline Smolensk & (LGR) & $2 \times 1500$ & 3000 \\
\hline Ignalina & (LGR) & $2 \times 1500$ & 3000 \\
\hline \multirow[t]{2}{*}{ Khme lnitsky } & (LGR) & $2 \times 1500$ & 2000 \\
\hline & & Total & 14000 \\
\hline
\end{tabular}

For an additional five sites (Zaporozhe, Rostov, Krymsk, Tatar, and "Khme 1nitsky II") we have no knowledge of the intended reactor type. If we assume a preponderance of PWRS and that three contain $4 \times 1000$-MWe PWRs ( 12000 MWe), and two contain $4 \times 1500$-MWe LGRS $(12000$ MWe), we derive a total of 24000 MWe. Little is known about these last five locations, but because they were identified in 1981 in the 1981-85 Plan, it seems likely that they could be completed by 1990.

Somewhat fortuitously the total that would be added by completion of these sites is 36000 MWe, which is very close to the previous estimates for the 1986-90 period. (Sec IV.A.3.b.)

c. Overall Projection to 2000

- For the three five-Year periods up to 1985, the installed capacity has approximately doubled in each successive period. This assessment is based upon adding the capacities of individual specific reactors as they have been, or are projected to be, brought on line. For the three periods, the added capacities are 3760,9200 , and 18440 MWe.

- For the 1986-90 period, the increase in size of installed reactors indicates a doubling of installed capacity even if the number of reactors does not increase. This would indicate an additional 35000 to 40000 MWe in this period. This period would probably see the substitution of PWRs for LGRS for economic reasons. Further support for this figure is given by an estimate of 36000 Mie, which would be installed if sites named in 1981 each possessed four reactors (principally PWRs) by 1990. 
- In 1990 the Atormash plant will be producing VVER-1000 units at a five-year rate of 35000 to 40000 MWe. We postulate that LGRs may not be built after 1990 (at least in quantity) and LMFBRs will not be constructed (again in quantity) until 2000.

- At the above rate, building and total capacities will be

\begin{tabular}{|c|c|c|}
\hline Period & $\begin{array}{l}\text { Added } \\
\text { (MWe) }\end{array}$ & $\begin{array}{c}\text { Final Capacits } \\
\quad \text { (MWe) }\end{array}$ \\
\hline $1971-75$ & 3760 & 5235 \\
\hline $1976-80$ & 9200 & 14435 \\
\hline $1981-85$ & 18440 & 32875 \\
\hline $1986-90$ & $35-40000$ & $68-73000$ \\
\hline $1390-95$ & $35-40000$ & $103-113000$ \\
\hline $1996-2000$ & $35-40000$ & $138-153000$ \\
\hline
\end{tabular}

These projections are lower than, but consistent with, the probably optimistic official projections (IV.A.3.a.). They give a nuclear $\mathrm{kW} / \mathrm{capita}$ value (based on present population of 264 million) of 0.52 to 0.58 in 2000 .

- Beyond 2000 the introjuction of the LMFBR makes projections very uncertain.

B. Bulgaria

1. Energy Overview and Muclear Policy. Bulgaria is energy poor and indigenous sources supply only about one-quarter of its total needs. Essentially all oil and gas (over $50 \%$ of total 1977 use) is imported, as is about half of the coal and some electricity. ${ }^{10}$ (Romanian and Bulgarian electricity networks are linked.) Because of this a very strong commitment has been made to nuclear power, which is intended to generate about one-third of Bulgaria's electricity (17-18 billion kWh/year) by 1985.11

There is no indigenous reactor manufacturing capability, and all existing and projected reactors of the PWR type are to be manufactured in the USSR, or possibly in Czechoslovakia.

2. Operating Reactors and Construction to 1985. All present and currently projected reactors are or will be located at a single site, Kozlodui, situated on the Danube in northeast Bulgaria on the Bulgaria-Romania border. 
The first four reactors are all VVER-440 types, the first two of which commenced operating in 1 ate 1974 and 1975. The two remaining reactors have been delayed about three years and should be on line in 1981 and 1982. Construction of a fifth reactor, a VWER 1000, has started, with a stated operating date of 1984, but in view of past delays 1987 appears more likely. All five reactors would have to be in operation to achieve the "one-third nuclear electricity" target stated for 1985.

3. Projected Capacity to 2000. Although there are no specific statements of Bulgarian intent beyond the fifth Kozlodui reactor, the nuclear program probably will follow the broad Comecon aim of nuclear power for one-half of all electricity generation by 2000. Provided Kozlodui can accommodate additional reactors or another site is developed, it seems reasonable that at least two additional 1000-MW units could be brought on-line in the 1990s.

In terms of Five-Year-Plan periods this would give the following projection (nominal power levels throughout).

\begin{tabular}{|c|c|c|}
\hline Period & $\begin{array}{l}\text { Added } \\
\text { (MWe) }\end{array}$ & $\begin{array}{l}\text { Final Capacity } \\
\text { (MWe) }\end{array}$ \\
\hline $1971-75$ & 440 & 440 \\
\hline $1976-80$ & 440 & 880 \\
\hline $1981-85$ & 880 & 3760 \\
\hline $1986-90$ & 1000 & 2760 \\
\hline $1991-95$ & 1000 & 3760 \\
\hline $1996-2000$ & 1000 & 4760 \\
\hline
\end{tabular}

Based on the present population of $8.9 \mathrm{million}$, this gives a nuclear $\mathrm{kW} / \mathrm{capita}$ of 0.53 in the year 2000, which is close to the USSR's 0.58 .

C. Czechoslovakia

1. Energy Overview and Nuclear Policy. Czechoslovakia has substantial indigenous supplies of coal that provide about two-thirds of its total energy needs (1977). The remaining third is almost all imported, principally as oil and gas with small quantities of electricity. 10 Thus there are strong 
incentives for alternative sources, and the intention is to obtain one-third of its electricity from nuclear plants by $1990^{12}$ and $50 \%$ by $2000 .^{13}$

Czechoslovakia (together with East Germany) is far more industrialized than the other Eastern European states and has a uniquely important role in the nuclear activities of the Soviet Bloc. By mutual agreement within Conecon, Czechoslovakia has specialized in the production of reactors for the entire Soviet Bloc as well as for export and possesses the only such capability outside the USSR. The reactors are VVER-440 PWRs and their manufacture has been, or is being, transferred from the USSR, which will concentrate on manufacture of the 1000-MWe VVER-1000 reactor at its Atommash plant (see Section IV.A.3.b.).

2. Nuclear Activities in Czechoslovakia. More than any other Soviet B loc country, except the USSR, Czechoslovakia has a long and many-faceted involvement in the nuclear power field (see Appendix for details).

An independent or semi-independent nuclear power program was initiated in the late ' 50 s by starting construction of a national uranium-fueled, heavywater moderated reactor. There was some USSR involvement in the design but also a significant Czech component, as well as indications of "the use of Czechoslovakia's own uranium and heavy water." Although the picture is clouded, there is clear evidence of Czech aggressiveness and independent attitude. This reactor project has a chequered history. The protracted 15-year construction period probably reflects the USSR's reservations about such an independent effort -- after her embarrassing experience, and subsequent falling-out, with China. This reactor was also the scene of an accident that killed two persons. Although still operating, there is no further development of the system, and there is now complete commitment to the USSR VVER reactor systems.

As indicated, there is a major Comecon reactor manufacturing effort, principally at the SKODA works at Plzen but with additional component manufacture elsewhere. The capacity is significant (see below) and may reach four to five per year for the 400-MWe system currently manufactured (for Comecon use and probably also for export). Extension of the plant to manufacture 1000-Me VVER units is conjectural but logical. Other comecon nations and Yugoslavia provide direct financial support of this operation. In addition, component manufacture contributes to the fast-breeder program. 
Uranium mining in Czechoslovakia predates World War II and continues but, like all such activities in the Soviet Bloc, under strong USSR control. Nevertheless, even here there are indications of increased Czech involvement. A further indicator of development is a report of construction of a reprocessing plant in conjunction with East Germany, but the lack of detail obscures how firm the plans actually are.

The joint constructioll, together with the USSR, Poland, and Hungary, of a nuclear plant at Khmelnitsky in the Ukraine has already been discussed (see USSR) with repayment of construction costs to nations other than the USSR in the form of imported electricity.

Finally, the only recent (1979) mention of construction of processheat reactors for Soviet $B{ }^{10 C^{14}}$ industrial use is at four sites in Czechoslovakia. These could be low-temperature light-water reactors as intended in the USSR (see IV.A.) but may be high-temperature gas-cooled units.

3. Operating Reactors and Construction to 1985. The only operating reactors are located at one site, Jaslovsk Bohunice (also known as Bohunice): the 104-MWe heavy-water reactor (start-up 1972) discussed earlier and two VVER-440 units started up in 1978 and 1980.

Two additional VVER-440 units are under construction at Bohunice with scheduled start-up in 1982 and 1983. Four VVER-440 units are under construction at Dukovany with scheduled start-ups in 1983, two in 1984, and 1985. Further, a VVER-1000 is scheduled for start-up in 1985 in Malovice (Southern Bohemia). Bearing in mind (1) the always-optimistic tone of official pronouncements and (2) the delay experienced by the first Bohunice VVER-440 units, it is prudent to assume that all the units under construction will be delayed one to two years. Thus, up to and including 1985, we assume the completion of two additional units at Bohunice (perhaps in 1984 and 85 ) and two at Dukovany (1984 and 185). The remaining Dukovany units $(2 \times 440$ Mke) and the Malovice VVER 1000 would be delayed beyond 1985 (see below).

In terms of five-year periods this would give

\begin{tabular}{crc} 
Period & $\begin{array}{c}\text { Added } \\
\text { (MWe) }\end{array}$ & $\begin{array}{c}\text { Final Capacity } \\
\text { (MWe) }\end{array}$ \\
\hline $1971-75$ & 104 & 104 \\
$1976-80$ & 880 & 984 \\
$1981-85$ & 1760 & 7744
\end{tabular}


This is consistent with, but somewhat smaller than, the official projection of 3500 Me by 1935 . $^{15}$

4. Construction beyond 1985. In the 1986-90 period the two delayed VVER-440 units at Dukovany and the VVER-1000 unit at Malovice (see above) should be completed.

At an additional site, Leviece (or Levice) in southern Slovakia, two VVER-440 units are scheduled to start up in 1987 and 1988. Eventually this site should contain four VVER 440s. Another named site is Mohovce (Slovakia) but with no indication of intended capacity or start-up dates.

In addition, locations have been mentioned in South Bohemia, Central Bohemia, South Moravia, and Central Slovakia but no specific locations, capacities, or start-up dates are given. We assume, without certainty, that the Central Slovakia site is Mohovce and South Bohemia is Malovice.

For the 1986-90 period we may safely assume the completion of Dukovany (2 $\times 440)$, the first 1000 -MWe unit at Maiovice, and the first two units $(2 \times 440)$ at Leviece. This gives 2760 MWe installed in this period for a total of 5504 MWe by 1990. Possibly the Leviece site could be completed in this period by the installation of two additional VVER 440s and a second VVER 1000 at Malovice (if we assume a minimum site capacity of about 2000 MWe corresponding roughly to $4 \times 440$ MWe as elsewhere). This would give a total by 1990 of 7384 MWe. Either of these figures is well short of the official projection of 10000 Mwe by $1990 .^{16}$

We may reasonably assume that all construction currently identified in South Bohemia (Malovice?), Central Bohemia, South Moravia, and Central Slovakia (Mohovce?) will be completed. If these are post-1990, then it is reasonable to assume they will contain VVER 1000s (not VVER 440s) and each site will contain at least two reactors. This may be a conservative conjecture because the sites could contain four such reactors, as in the USSR. In addition there may be additional sites not yet identified.

Considering only the identified sites, their completion would give the following capacities (on the above assumptions). 
Total Site

Capacity

(MWe)

Bohunice $(1 \times 104,4 \times 440)$

1864

Dukovany $(4 \times 440)$

1760

Leviece $(4 \times 440)$

1760

Malovice (South Bohemia) $(2$ or $4 \times 1000)$

Central Bohemia ( 2 or $4 \times 1000$ )

South Moravia ( 2 or $4 \times 1000$ )

Mohavce (Central Slovakia) $(2$ or $4 \times 1000)$

\begin{tabular}{lll}
2000 & or & 4000 \\
2000 & or & 4000 \\
2000 & or & 4000 \\
2000 & or & 4000 \\
\hline
\end{tabular}

Total 13384 or 21384

Because the USSR has an abundance of major rivers that provide sufficient cooling water for large reactor stations, and Czechoslovakia does not, the lower of the two projections (corresponding to 2000 MWe per station) is more probable.

Regarding timing, completion by 1995 of reactor sites named in 1981 seems reasonable, particularly if each site has a capacity of only 2000 MWe.

In summary then, the construction at identified sites would indicate a total capacity of 5504 to 7384 MWe (a mean of 6444 MWe) by 1990 and 13384 by 1995.

5. Projected Capacity to 2000. Taking the data of the two previous sections and the average, 3700 MWe, of the two estimates (2760 and 4640 MWe) of the installed capacity in the 1986-90 period, we can derive a projection up to 1995. This summary, given below, also includes the capacity installed in the last Five-Year Plan by taking the difference of the total capacities in 1990 and 1995.

\begin{tabular}{llll}
$\frac{\text { Period }}{1971-75}$ & $\begin{array}{c}\text { Capacity/Period } \\
\text { (MWe) }\end{array}$ & & $\begin{array}{c}\text { Final Capacity } \\
\text { (MWe) }\end{array}$ \\
\cline { 2 - 2 } & 104 & & 104 \\
$1976-80$ & 880 & & 984 \\
$1981-85$ & 1760 & & 2744 \\
$1986-90$ & 3700 & & 6444 \\
$1991-95$ & 6940 & & 13384
\end{tabular}


It is interesting to note that, apart from the very beginning, we estimate that the pattern is identical to that of the USSR, with an approximate doubling of the installed capacity in each successive five-year interval. As with the USSR, this results partly fror an increase in the individual reactor size from 440 to 1000 MWe.

In the case of the USSR, we argue that the rate of installation will be approximately constant after 1985 (at least up to 2000). It is tempting to postulate the same trend in Czechosiovakia but delayed five years to 1990 because of the later start. In both cases the trend is due partially to the maturity of the manufacturing plants at Volgodonsk and Plzen.

Making this assumption and rounding off the figures after 1985 gives the following best estimate.

\begin{tabular}{lcc} 
Period & $\begin{array}{c}\text { Capacity/Period } \\
\text { (MWe) }\end{array}$ & $\begin{array}{c}\text { Final Capacity } \\
\text { (MWe) }\end{array}$ \\
\cline { 2 - 3 } $1971-75$ & 104 & 104 \\
$1976-80$ & 880 & 984 \\
$1981-85$ & 1760 & 2744 \\
$1986-90$ & 3700 & 6500 \\
$1991-95$ & $: 7000$ & 13500 \\
$1996-2000$ & 7000 & 20500
\end{tabular}

$\overline{a_{\text {Rounded off }}}$ after 1985.

A final point of interest is that this gives a nuclear kilowatt per capita (based on the present populating of 15.2 milition) of 1.35 , which is more than twice that of the USSR. This is not unreasonable considering the greater urbanization of czechoslovakia and the fact that it has fewer alternative sources of energy than the USSR.

D. German Democratic Republic (GDR)

1. Energy Overview and Nuclear Policy. The GOR is in the same relatively fortunate position as Czechoslovakia in that it produces about $70 \%$ of the energy it consumes. The indigenous energy is overwhelmingly in the form of lignite (the GDR is one of the world's greatest producers, over 250 million 
tons/year), and the 30\% imported energy is almost entirely oil and gas. The GDR has gas reserves (supplying about half of total use) but no 011 production. 10

In terms of primary production of electricity, nuclear reactors are much more significant than hydroelectricity $(4$ to 1 in total electricity generated in 1977), but the nuclear power program has a surprisingly low profile considering the GDR's import level of energy and its high industrial and technical capability. Apart from a first, quite small reactor, all systems are of the VVER type manufactured either in the USSR or, in the future, in Czechoslovakia, and official projections of the level of nuclear power are muted or absent.

Therefore the nuclear policy is not clearly expressed, but as part of Comecon, can be expected to follow the general comecon trend toward more nuclear units to counter pressing energy problems. 17

2. Operating Reactors and Construction. The first GDR venture was a small 70-MWe PWR built jointly by the GDR and the USSR at Rheinsburg (Greifswald in the Granesee region). Although intended for operation in 1960, it was completed only in 1966.

All reactors now in operation or projected are of the VVER type. The only operating reactors (apart from Rheinsburg) are three VVER 440s in the Nord plant at Lubmin (also near Greifswald). These reactors came on line in 1973, 1975, and 1978 and were completed expeditiously, either being almost on line or even ahead of schedule. The excellent construction record for these reactors is slipping as a fourth Nord reactor (also a VVER-440), originally scheduled for 1978, probably will be completed in 1981.

This slippage is also evident at the second major site at Magdeburg where two VVER-440s scheduled for completion in 1980 are still incomplete. A more likely date is perhaps 1984 in view of the delay of the fourth Nord unit and some recent (1981) indications of delays in the GDR program. ${ }^{18}$ This report not only indicates delays (for undetermined reasons) but also mentions the specific delay of a VVER-1000 unit beyond the original date of 1985 at Stendal. The Stendal location and the increased reactor size have not been mentioned elsewhere, and it seems unlikely that the 1985 start-up date is correct. 
Ignoring the small unit at Rheinsburg, the present capacity (in 1981) is 1320 MWe, 880 of which was installed in the 1971-75 period and 440 MWe in 1976-80.

3. Projection to 2000. In considering projections we have very little information beyond that in the previous section. We may reasonably infer that the Magdeburg site eventually will contain four VVER 440s, the additional two being completed in the 1986-90 period. We may also assume that the Stendal site will, at some time, be brought into operation and that it will contain two VVER 1000s to give a capacity roughly equal to that of Lubmin and Magdeburg $(4 \times 440 \mathrm{MWe})$. One of the Stendal units could be completed in 1986-90 but completion of two seems unlikely.

This would give

$$
\begin{aligned}
1981-85-- & \text { Nord } 2.2 \text { (No. 4) in } 1981 \text { plus Madgeburg } 1 \text { and } 2 \text { (1984) } \\
& \text { for a total of } 3 \times 440 \text { (1320 MWe) } \\
1986-90 ~-- & \begin{array}{l}
\text { Magcieburg } 3 \text { and } 4 \text { plus Stendal } 1 \text { for a total of } 1880 \\
\text { MWe. }
\end{array}
\end{aligned}
$$

Beyond 1990 we can reasonably assume a somewhat expanded program, but past performance of the GDR does not indicate a massive expansion.

Taking these arguments into account, we project the following nuclear capacity.

\begin{tabular}{lccc} 
Period & $\begin{array}{c}\text { Capacity/Period } \\
\text { (MWe) }\end{array}$ & & $\begin{array}{c}\text { Final Capacity } \\
\text { (MWe) }\end{array}$ \\
\cline { 2 - 2 } & 880 & & 880 \\
$1976-80$ & 440 & & 1320 \\
$1981-85$ & 1320 & & 2640 \\
$1986-90$ & 1880 & & 4520 \\
$1991-95$ & 3000 & 7500 \\
$1996-2000$ & 3000 & 10500
\end{tabular}

The speculative nature of the projection, particularly beyond 1990, is obvious. Some minor reassurance regarding the 2000 figure of about 10000 me can be gained by noting that the nuclear capacity per capita based on the present population of 16.8 million is $0.6 ?$, which is about the same as in the 
USSR. This, if correct, would indicate that, although the GDR is roughly comparable to Czechoslovakia in both energy supply and industrial capability, the GDR has a more conservative approach to nuclear power.

\section{E. Hungary}

1. Energy Overview and Nuclear Policy. Hungary has significant indigenous supplies of lignite and gas but is still forced (in 1977) to import almost half its energy. About $40 \%$ of the energy use is from oil, essentially all of which has to be imported, together with lesser quantities of hard coal, gas, and electricity. ${ }^{10}$ There is some indigenous uranium mined under USSR control.

There is an ambitious nuclear electricity program even though the first reactor has not yet been commissioned. The intent is to have 10000 to 12000 MWe, all from VVER 440 s or VVER 1000 s, by the year $2000,{ }^{19}$ which represents more than $50 \%$ of the total installed capacity.

Together with the USSR, Poland, and Czechoslovakia, Hungary is contributing financially (12.5\%) to the construction of the 4000-MWe Khmelnitsky plant in the Ukraine. The contribution will be repaid as imported electricity in the period 1984 to 2003, after which the plant will be entirely owned by the USSR (see Section IV.A.2 USSR).

2. Reactors under Construction. The oniy identified site is Paks situated on the Danube south of Budapest. This site is intended to contain four VVER-440 units initially and later an additional three VVER-1000 reactors for a total capacity of 4760 MWe. For comparison, the total Hungarian capacity (a)1 non-nuclear) in 1979 was 4100 MWe. ${ }^{19}$

Although the first two plants (VVER 440s) were intended for completion in 1980, they are now projected for 1982 and '83; and units 3 and 4 (also 441) MWe) that were planned for 1984 and ' 85 would seem more likely to be completed by 1986 or ' 87 at the earliest. The first VVER-440 unit was also the first reactor to be completed in Czechoslovakia.

It has been stated that the three VVER-1000 reactors (presumably from the USSR) would be completed in the 1987-90 period, but this seems improbable in view of the other construction delays at Paks. 
3. Projection to 2000. As indicated above, Paks 1 and $2(2 \times 440$ MWe $)$ should be completed before 1985, and 3 and 4 ( $2 \times 440$ MWe) before 1990. One of the three 1000-MW units probably could be completed by 1990 and the remaining two by 1995. This exhausts the identified reactors but it is unlikely that additional reactors will be constructed by 2000. We assume that all of the additional units will be 1000 MWe and that four to six of these will be in operation by 2000.

A surmary of the projections is as follows.

\begin{tabular}{|c|c|c|}
\hline Period & $\begin{array}{c}\text { Capacity } \\
\text { Installed in Period } \\
\text { (MWe) } \\
\end{array}$ & $\begin{array}{l}\text { Final Capacity } \\
\text { (MWe) }\end{array}$ \\
\hline $1981-85$ & $(2 \times 440) 880$ & 880 \\
\hline $1986-90$ & $(2 \times 440,1 \times 1000) 1880$ & 2760 \\
\hline $1991-95$ & $(3 \times 1000) 3000$ & 5760 \\
\hline $1996-2000$ & $(3-5 \times 1000) 3000-5000$ & $8760-10760$ \\
\hline
\end{tabular}

This projection is only slightly lower than the official statement of 10000 to 12000 MWe and gives the high value of 0.82 to 1.01 nuclear kilowatt per capita for Hungary, based on the present population of 10.7 million.

F. Poland

1. Energy Overview and Nuclear Policy. Poland is the only country in the Soviet BIOC, other than the USSR, that has a net surplus of energy. This arises because of its high coal production (mostly hard coal) allowing exports of about 40 million tons in 1977. Poland also produces most of the gas it uses, but essentially no oil. Because of this favorable energy balance there seems to be little sense of urgency, despite official statements, about major use of nuclear power for electricity and heat production by 2000.20 The entire program is based upon VVER reactors but none are yet in operation, so that Poland will be the last Comecon country to enter the nuclear energy field. Together with the USSR, Hungary, and Czechoslovakia, Poland is funding (25\%) the Khmelnitsky nuclear plant in the Ukraine and will receive a proportional share of its output between 1984 and 2003 (see USSR section IV.A.2). 
2. Reactors under construction. Only two sites have been identified, Zarnowiec Lake near Gdansk on the Baltic coast, and Kujawy in central Poland.

At Zarnowiec there are two VVER-440 reactors under construction and these may be connected with a pumped storage scheme of 680 -MWe capacity. ${ }^{20}$ The construction picture is muddled, with initial start-up dates given as 1983, 1985, 1986, and 1987 as well as statements that "construction will begin this year" (1981) (see Appendix). Completion in 1987-88 seems reasonable, particularly since official criticism of the slow tempo has now appeared. 21

The Kujawy site reactor is of unknown capacity and will be built "after 1985."

3. Projection to 2000. Early statements (1976) mentioned $13 \%$ of electricity generation being nuclear by 1990 and $40 \%$ by $2000 .{ }^{20}$ Later statements (1977) projected 8500 MWe of nuclear capacity by 1990, and very recently (January 1981) a target of 20000 to 23000 MWe by 2000 was given. ${ }^{22}$ These projections seem excessively optimistic even ignoring Poland's grave economic and social problems because poland has such a late start in the nuclear field.

We may reasonably assume Zarnowiec will be completed with four VVER 440s, the first two in 1987-88 $(2 \times 440)$, and the second two in the period 1990-95. If we assume that Kujawy will be post-1990, then it is reasonable to postulate that these will be VVER-1000 units and probably two will be built on the site. These could also be completed in the 1990-95 period $(2 \times 440$ plus $2 \times 1000$, total $2880 \mathrm{MWe})$. The next Five-Year Period could also see the construction of four reactors, at two undesignated sites, all of which would probably be 1000-MWe units.

The projection to 2000 is therefore as follows:

\begin{tabular}{llc} 
Period & $\begin{array}{c}\text { Constructed } \\
\text { in Period } \\
(\text { MWe) }\end{array}$ & $\begin{array}{c}\text { Final Capacity } \\
\text { Period } \\
\text { (MWe) }\end{array}$ \\
\hline $1986-90$ & $(2 \times 440) 880$ & 880 \\
$1991-95$ & $(2 \times 440,1 \times 1000) 2880$ & 3760 \\
$1996-2000$ & $(4 \times 1000) 4000$ & 7760
\end{tabular}

This is far short of the official figure of about 20000 Whe and, on the basis of the 1977 population of 35.4 million, would give a nuclear capacity 
per capita of only $0.22 \mathrm{~kW}$ in the year 2000. This situation is comparable to that of Romania (see below), which also has major indigenous energy sources.

\section{G. Romania}

1. Energy Overview and Nuclear Policy. Romania's energy policy is strongly influenced by (1) her large indigenous sources of oil and gas, (2) her highly independent* attitute toward Comecon and the USSR, and (3) to difficulties with hard currency and trade with the West.

Romania produces over $90 \%$ of the energy consumed and, most importantly, until 1975 was self-sufficient in both $0 i 1$ and gas, needing only to import coal. Since 1975 these happy circumstances have deteriorated slightly, and there seems little doubt that the decrease in oil and gas production will accelerate, thus creating significant problems. These problems are probably not helped by the somewhat antagonistic relations with the USSR and the rest of Comecon, which came to a head when Romania took China's side in the SinoSoviet dispute that started when Kruschev was in power. ${ }^{23}$

Although one VVER-440 reactor is under construction (at 01t, near Bucharest), this is apparently the only such unit that will be built and Romania has ambitious $p$ lans for the construction of as many as 12 to 16 natural-uranium heavy-water reactors by 2000. Negotiations have been principally with Canada, and one 600-MWe CANDU reactor is under construction. These difficult and prolonged negotiations result from two major problems: first, the lack of hard currency necessitates barter arrangements; and second, Romania is aiming at technology transfer (to build up its own manufacturing capability) that is much more demanding than Western organizations find reasonable. As a result, although the Romanian Government would like a strong nuclear program, its payment problems and strong demands raise great doubts about the outcome (see Appendix for details).

2. Reactors under Construction. The VVER-440 reactor at 01t originally was scheduled for start-up in 1980 but is now projected for 1983. The only

*In the past year there have been indications that Romania's self-sufficiency in oil and gas is ending and, like other Soviet Bloc members, she is becoming dependent upon USSR energy sources. 
CANDU reactor under construction is at Cernavoda in the lower reaches of the Danube not far from the Black Sea. This 600-MWe reactor is scheduled for start-up in 1987. No other sites are identified and there are no specific plaris for additional rear.tors at these two sites.

3. Projection to 2000. The above construction will give 440 MWe by 1985, and a further 600 MWe by 1990. Additional reactors before 1990 are unlikely and construction after this period would seem to depend entirely upon resolution of the trade problems with Canada or other countries. The pressure for Romania to introduce nuclear power will increase as time progresses, and this certainly will lead to less stringent bargaining. We assume that events will move much more slowly than originally planned, and that only six of the twelve reactors will be built by 2000 .

The projected capacity is as follows.

\begin{tabular}{lcc} 
Period & $\begin{array}{c}\text { Capacity } \\
\text { Installed in Period } \\
\text { (MWe) }\end{array}$ & $\frac{\begin{array}{c}\text { Final Capacity } \\
\text { (MWe) }\end{array}}{1981-85}$ \\
\cline { 2 - 3 } $1986-90$ & $(1 \times 440) 440$ & 440 \\
$1991-95$ & $(1 \times 600) 600$ & 1040 \\
$1996-2000$ & $(2 \times 600) 1200$ & 2240 \\
$13 \times 600) 1800$ & 4040
\end{tabular}

On the basis of the 1977 population of 22.1 million, this gives a nuclear capacity per capita of only $0.18 \mathrm{~kW}$ in the year 2000, compared to USSR's 0.58 .

V. SUMMARY OF SOVIET BLOC PROJECTIONS TO 2000

The projections obtained for the individual countries are summarized in Table $v$. The data have been rounded off and are presented as gigawatts of electric capacity (GW or 100 MWe) installed by the end of the given five-year period.

The contribution of the countries other than the USSR rises from about $20 \%$ of the total in the early years to about $30 \%$ in 2000 . This change reflects the effect of the later starts in nuclear energy in several of the satellite countries. 
TOTAL PROJECTED CAPACITY (GW) INSTALLED IN FIVE-YEAR PERIODS TO YEAR 2000

\begin{tabular}{lcccccc}
\hline \multicolumn{1}{c}{ Country } & $\begin{array}{r}1971 \\
-75\end{array}$ & $\begin{array}{r}1976 \\
-80\end{array}$ & $\begin{array}{c}\text { Five-Year } \\
1981 \\
-85\end{array}$ & $\begin{array}{r}1986 \\
-90\end{array}$ & $\begin{array}{r}1991 \\
-95\end{array}$ & $\begin{array}{r}1996 \\
-2000\end{array}$ \\
\hline Bulgaria & 0.4 & 0.9 & 1.8 & 2.8 & 3.8 & 4.8 \\
Czechos lovakia & 0.1 & 1.0 & 2.7 & 6.5 & 13.5 & 20.5 \\
GDR & 0.9 & 1.3 & 2.6 & 4.5 & 7.5 & 10.5 \\
Hungary & -- & -- & 0.9 & 2.8 & 5.8 & 9.8 \\
Poland & -- & -- & -- & 0.9 & 3.8 & 7.8 \\
Romania & & & 0.4 & 1.0 & 2.2 & 4.0
\end{tabular}

Total other

than USSR

1.4

3.2

8.4

18.5

36.6

57.4

\begin{tabular}{llllllll}
\hline USSR & 5.2 & 14.4 & 32.9 & $6 \varepsilon-73$ & $103-113$ & $138-153$ \\
\hline Grand Total & 6.6 & 17.6 & 41.3 & $87-92$ & $140-150$ & $195-210$ \\
\hline
\end{tabular}

As noted earlier, the installed nuclear capacity per capita (kW/capita) in the year 2000 ranges from a low of about 0.2 for the latecomers, Poland and Romania, to about 1.3 for Czechoslovakia. Hungary is also high $(0.9)$, whereas the others (USSR, Bulgaria, GOR) are about 0.5 . These differences reflect both the availability (or lack) of indigenous energy supplies and specific national attitudes and policies.

The accuracy of the projections is very difficult to assess but is certainly worse than indicated by the ranges given for the later years. Two 
important points are (1) these projections are likely to be conservative for the later years and (2) the actual contribution of nuclear energy will probably be higher than indicated. For electricity generation we have postulated the phasing-out of USSR LGRs as PWR-manufacturing capability increases; this may not be the USSR's choice. Additionally, we have ignored (as smal1) the LMFBR contribution. This latter assumption is reasonable, but the former one (on LGRs) may not be.

Finally, the nuclear contribution to the Soviet Bloc economies is not solely electricity generation but also heat. This will include the "waste" heat from electricity generation, which, if used, approximately doubles the total energy supplied. It seems probable that some, but by no means all, of the nuclear electric stations will be used in this way. In addition, there will be major contributions to space heating cities by reactors specifically built for this purpose and these are not considered here.

overall, the inescapable conolusion is a major comitment by the soviet Bloc to the widespread use of nuclear energy whenever and in whatever form is advantageous. It is not viewed as an energy form that must be used reluctantly but as a well-proven boon that can be used to replace more expensive and depleting energy from other sources. The 2lst century should see an even wider and larger use of nuclear power in the Soviet Bloc with continued substitution of nuclear energy for other forms of electricity generation, greater overall use of electricity, nuclear space heating, pumped-storage, and combined nuclear and non-nuclear plants, and probably hydrogen generation by nuclear means.

\section{REFERENCES}

1. "A New Look at Soviet Electric Power," Cur. Dig. Soviet Press XXXII, No. 22, 1 (July 2, 1980).

2. "Surveying the USSR's Energy Future," Cur. Dig. Soviet Press XXXIII, No. 9, 1 (Apri1 1, 1981).

3. "Draft Guidelines for 11th Five-Year Plan," Cur. Dig. Soviet Press, XXXII, No. 48, 1 (December 31, 1980).

4. "Major Construction Projects for 1981," Cur. Dig. Soviet Press, XXXXIII, No. 1, 8 (February 4, 1981).

5. Gloria Duffy, "Soviet Nuclear Energy: Domestic and International Policies," Rand Corporation report R-2362-D0E (December 1979). 
6. "The Soviet Union expects to have 13,000-13,500 MW of Nuclear Power Capacity," Nuc1. Week, 27, 13 (July 3, 1980).

7. "Soviet authorities claim to have finished the first pressure vessel," Nuc1. Heek, 22, 10 (February 26, 1981).

8. "Soviet Atommash Plant Reveals Some Progress, Many Problems," Nucl. Week, 20, 12 (November 8, 1979).

9. "The second 1,000-MW unit at the Kursk nuclear plant has started up," Nuc 1. Heek, 20, 15 (February 15, 1979).

10. "Energy Supplies in Eastern Europe," CIA publication NISUB-E-280-105, (December 1979).

11. "Construction of a fifth unit at Bulgaria's Kozlouchei nuclear station," Nuc1. Week, 2112 (July 17, 1980).

12. "World Politics: Europe -- Czechoslovakia," Cur. Dig. Soviet Press, XXXII, No. 30, 14 (August 27, 1980).

13. "World Markets -- a review of existing work and future prospects -Czechoslovakia, Soviet Union," Nucl. Eng. Int. 23, 11 and 21 (October 1978).

14. A. Keilberth and R. Smith, "First nuclear power fatal accident appears to have been at Czech plant," Nucl. Week, 20, 3 (February 1, 1979).

15. "Nuclear plants will generate more than a third of Czechoslovakia's electricity by 1990," Nuci. Week, 21, 6 (July 31, 1980).

16. "Uranium plant opens rich vistas for Comecon," Nucl. Eng. Int., 24, 6 (September 1979).

17. "Comecon Stresses the Energy Crunch," Curr. Dig. Soviet Press, XXXXI, No. 25, 10 (July 23, 1980).

18. "N-Power Setback in E. Germany," Financial Times (London), April 22, 1981.

19. "Czechoslovakia has completed building its first Soviet-designed 440-MW PWR," Nucl. Week, 21, 16 (March 13, 1980).

20. "Poland's nuclear plans," Nucl. Eng. Int. 21, 10 (January 1976).

21. "Poland's Communist party paper 'Trybuna Luda' criticized," Nucl. Week 21, 6 (January 3, 1980).

22. "Poland will start construction of its first nuclear station this year," Nuc l. Week 22, 5 (January 29, 1981).

23. R. F. Starr, Ed., Yearbook on International Communist Affairs (1980) (Hoover Institution Press, Stanford, 1981) pp. 67-92. 
APPENDIX

DETAILS OF SOVIET BLOC NUCLEAR POWER

This appendix contains brief statements of essentially all the specific facts used to construct the text of this report. Most frequently a particular piece of information will be given as a very brief news item and the overall perspective must be obtained by accumulating this kind of information. This means that information is usually fragmentary, sometimes contradictory, and often should be treated with a certain reserve.

For convenience, the references for each country are given at the end of each section. For concise summaries of much of the information available, the "World List of Nuclear Power Plants," published each six months in Nuclear News, and the detailed publication of "Power Reactors (General Information, Technical Data, Progress Schedules)" published by Nuclear Engineering International are invaluable.

I. USSR

A. Reactor Types and Location

This section is devoted to reactors that are operating, under construction, or planned for electrical or heat production.

The stations are discussed in order of first operation or announcement. These dates are not always completely clear and the order is therefore only approximate. Incomplete lists of reactors are given in Refs. 1 and 2 . The code number sometimes given in the text (for example 009 SU G) is the identification number of a reactor given in Ref. 2 .

Where possible, the latitude and longitude of each station is given; the usual convention of, for example, $\left(57^{\circ} 22^{\prime} \mathrm{N}, 94^{\circ} 20^{\prime} \mathrm{E}\right)$ will be replaced by the abbreviation 57.22, 94.20 where the " $N$ " and " $E$ " are implied.

Each station will be given a letter designation (Troitsk $=\mathrm{T}$ ) and each reactor a number; thus $\mathrm{T} 3$ would be the third Troitsk reactor. 


\section{Troitsk (T) $(54.08,61.33)$}

This station is identified as being in siberia and is presumably the Troitsk located near Sverdlovsk.

There are six reactors identified as light-water-cooled graphite reactors (LGR)(009 SU G). The first start-up was December 1958 (hereafter given as $12 / 58$ ) but dates between this and 1964 are also given. 1,2

Each reactor generates only 100 MWe and they, like the British reactors, presumably were constructed for joint plutonium (weapons) production and electricity generation.

\section{Be loyarsk (B) $(56.47,61.28)$}

This site is in the Sverdlovsk region and its first two reactors are only 100 MWe and 200 MWe (036 SU G; 071 SU G). They are both LGRs, as are those at Troitsk, and started up in April 1964 and October 1967.

This is also the site of a 600 -MWe fast-breeder reactor that started up in the first quarter of $1980^{3-5}$ (184 SU F), and it is thus one of the deve ?opment stations for this type of reactor. It is a pool-type sodium-coolea reactor. 6

3. Novovoronezh (N) $(51.40,39.13)$

This site is located in the Voronezh region. Its principal role has been as the development site for the Soviet PWR. Five PWRs of progressively larger size are in operation. $1,2,7,8$

\begin{tabular}{|c|c|c|c|}
\hline $\begin{array}{c}\text { Reactor } \\
\text { Designation } \\
\end{array}$ & $\begin{array}{l}\text { NEI } \\
\text { Code }\end{array}$ & $\begin{array}{l}\text { Capacity } \\
\text { (MWe) } \\
\end{array}$ & $\begin{array}{c}\text { Start-up } \\
\text { Date }\end{array}$ \\
\hline NI & 043 SU $P$ & 210 & $10 / 64$ \\
\hline N2 & 085 SU P & 365 & $12 / 69$ \\
\hline$N 3^{\mathrm{a}}$ & 104 SU P & 440 & $6 / 72$ \\
\hline$N 4^{a}$ & 104 SU P & 440 & $4 / 73$ \\
\hline$M 5^{b}$ & 186 SU P & 1000 & $1980^{C}$ \\
\hline
\end{tabular}

\footnotetext{
a Presumably prototypes of the now-standard VYER 440. bresumable the prototype of the standard VVER 1000. cstart-up date unclear. ${ }^{3}$
} 
It is interesting to note that the choice of the 1000-Mile size, which is less than that used in the West, may have been dictated by transport considerations, 9

A point of great interest is that one of the nuclear stations for district heating is being constructed at this site. ${ }^{5}$ No size, type, nor completion date are given, and it is presumably a new reactor specifically designed for this purpose--possibly a project adapting an existing reactor.

\section{Kola (K) $(68.53,33.01)$}

This site is at Kola near Murmansk. Little is known about the site, but there are reportedly four standard VVER-440 PWR reactors. ${ }^{1,2} \mathrm{~K} 1$ and $\mathrm{K} 2$ (134 SU P) started up in October 1973 and December 1974 and $K 3$ and $K 4$ (577 SU P) apparently in 1980. This was the first major oeployment of PWR systems.

\section{Bilibino (BI) (68.08, 166.35)}

This site is located in the extreme northeast in the town of Bilibino in Chukotka above the Arctic circle. ${ }^{10}$ The station consists of four 12-MWe boiling-water reactors (BWR) (144 SU B), but it is not clear if these are also water-moderated or graphite moderated. It seems more probable that they are the former. These reactors were designed for remote locations and supply both heat and electricity, including heat for food growing. The town of Bilibino has a population of 100000 with winter temperatures be low $-60^{\circ} \mathrm{C}$. The reactors possibly may supply all of the heat and electricity for this community. Operation commenced in 1974.

\section{Leningrad (L) $(59.55,30.25)$}

The Leningrad station represents the first deployment near a major city in the industrialized portion of the USSR and the first deployment of graphite-moderated reactors for electricity generation. There are four 1000-MWe reactors, all of which are water-cooled graphite systems, where the water boils in the coolant channels. ${ }^{1,2}$ The Russian designation of these reactors, RBMK, stands for "large-capacity boiling-water reactor."

The first three of these reactors suffered delays of perhaps one to two years from the original dates $3,13,11$ but are now operating effectively. The fuel is enriched from 1.1 to $1.8 \%$, presumably for power-flattening in the core. ${ }^{2}$ core loading is 30 tons. 13 


\begin{tabular}{|c|c|c|c|}
\hline $\begin{array}{c}\text { Reactor } \\
\text { Designation }\end{array}$ & $\begin{array}{l}\text { NEI } \\
\text { Code } \\
\end{array}$ & $\begin{array}{c}\text { Capac ity } \\
\text { (MWe) }\end{array}$ & $\begin{array}{c}\text { Start-up } \\
\text { Date }\end{array}$ \\
\hline $\mathrm{Ll}^{\mathrm{a}}$ & $187 \mathrm{SU} \mathrm{G}$ & 1000 & 1974 \\
\hline$L 2^{\mathrm{a}}$ & $213 \mathrm{SU} G$ & 1000 & 1975 \\
\hline $13^{b}$ & 585 SU G & 1000 & $2 / 80$ \\
\hline $14^{2}$ & $585 \mathrm{SU}$ G & 1000 & 1981 \\
\hline
\end{tabular}

aRefs. 1 and 2 .

Befs. 11 and 12 .

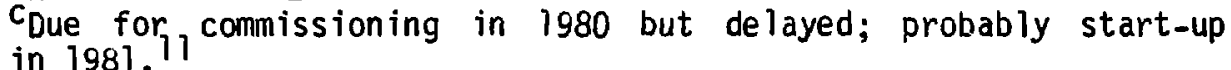

7. Kursk (KU) (51.45, 36.14)

Kursk is intended to have four 1000-MWe LGRs of the same type as at Leningrad. ${ }^{1,2}$ This will be the center of a new industrial complex that will be exploiting the mineral resources in the Kursk Magnetic Anomaly.* An artificial lake has been constructed along the River Seym to provide cooling water. 7

Unit KU 1 (188 SU G) started in $176^{1}$ and KU 2 (214 SU G) in $179 .^{14}$ Both units were appreciably delayed. 3,14 The third unit is under construction but also is delayed and may start up in $181 .^{5}$ The fourth unit may be under construction and is intended for start-up during the current 1981-85 Five-Year Plan. 15,16

Construction time for $K U 1$ was six years but KU 2 only took three years because of special methods used. 14

8. Armenia (A) $(41.00,44.00)$

This site is not precisely located but is in the Ararat valley near the border with Turkey and Iran. It has been reported as being at Metsamor, 11 at Oktembryan, ${ }^{2}$ or near Erevan. ${ }^{7}$

It has two standard VVER-440 PWR units; Al (189 SU P) was commissioned in $1976^{1,2}$ and A2 (189 SU P) in early $180^{11,17}$ Initially it was reported that an earthquake-resistant 1000-MWe graphite-moderated reactor would be built, but this was replaced by the PWR units.

There are no apparent plans to add to the reactors at this site.

* So named because of the disturbing effects on compass needles from the concentration of iron ore. 


\section{Chernobyl (C) $(51.16,30.15)$}

This station is located in the northernmost portion of the Ukraine north of Kiev. It is probably located on the Pripet river, which is a tributary of the onieper river.

There are two operating reactors, a third under construction and a fourth projected. $C 1$ and $C 2$ are 1000-MWe LGRs of the Leningrad type ${ }^{7,2}$ (549 SU G), which were commissioned in 78 and $179 .^{1}$ C3 and C4 are also 1000 MWe and reported in Ref. 1 as PWRs. This appears to be incorrect as they are given as LGRS elsewhere, $5,18-20$ and it seems more probable that a single type would be installed at a given station. C3 was supposed to be in operation by December $1980,{ }^{19}$ but there are extensive reports of delays ${ }^{18-20}$ and late 181 is more probable. The problems are in the normal industrial aspects of constructicn and relate to delays in concrete and steel delivery, not to specifically nuclear items. There is also a problem in providing accomodations, schools, and stores for workers.

Expansion of the Chernobyl capacity in the 1981-85 Five-Year Plan period is intended, $5,15,16$ and this presumably means the completion of the fourth reactor.

\section{Rovno (R) $(50.39,26.10)$}

This site, also known as West Ukraine, is situated in the Polesye region near "íne new atomic city of kuznetsk." 21 It is apparently planned as a PWR site with units $R 1$ and $R 2$ ( 550 SU $P$ ) being VVER 440s and a planned unit $R 3$ (576 SU P) a VVER 1000. 1,2

Unit RI was commissioned in December $1980^{22}$ and a second unit is "slated for delivery" in ' 81.22 Since $R l$ was originally planned for "76 start-up ${ }^{1}$ but was commissioned in ' 80 , the planned date of ' 80 for $R 2$ is more likely to be ' 84 .

The Five-Year Plan for 1981-85 calls for increased capacity at Rovno in the plan period, ${ }^{16}$ and completion of the 1000-MWe unit R3 by ' 85 seems feasible.

No additional units have been announced, but because most USSR stations seem to be aimed at an ultimate capacity of about 4000 Me, addition of two more VVER-1000 PWRs beyond 1985 may be intended. 


\section{Nikolayev (NI) $(46.57,32.00)$}

This site, also known as South Ukraine, is located on the. South Bug River to the northwest of Odessa. The station is intended to contain four VVER-1000 PWRs constructed at the new Atommash plant at Volgodonsk (see IV.A.3.b). (NI 1 and 2 (559 SU P), NI 3 and $4(579 \text { SU P })^{2}$ ).

Unit 1 should have been commissioned in $180,^{\prime}$ but there were extensive delays in non-nuclear construction of the plant as well as in apartments, schools, and stores for the construction workers. ${ }^{20,25}$ Completion of NI 1 in ' 81 or ' 82 should be feasible and perhaps NI 2 by ' 85 . Expansion of capacity in the 1981-85 Five-Year Plan ${ }^{5,16}$ probably refers to the completion of NJ 2. Completion of NI 3 and 4 seems more probable beyond ' 85 , perhaps by 90 . This station is part of a combined nuclear/hydro/pumped-storage complex in conjunction with the $1600-$ MWe Tashlyk hydroelectric station, the Konstantinovskkoje 380-MWe combined hydro/pumped-storage station, and the Alexsandrovska hydro complex. Water for drinking and irrigation and warm water for fish farming will be supplied. ${ }^{23}$

\section{Smolensk (S) $(54.49,32.04)$}

The Smolensk site (about 250 miles east of Moscow) is currently planned to contain two 1000-MWe LGRs of the Leningrad type (548 SU G). ${ }^{1,2}$ S1 and S2 were intended for start-up in 77 and 78 , but extensive delays in construction of the plant and apartments, etc. for construction workers are reported. 20,24 S1 start-up in 181 or 182 seeins probable. The Five-Year Plan calls for expansion at Smolensk in the 1981-85 period, $5,15,16$ and this presumably refers to start-up of S2.

No additional units have been announced, but since most sites seem to be aimed at 4000-MWe capacity, an additonal two 1000-MWe LGRs beyond 1985 are possible.

\section{Kalinin (KA) $(56.49,35.57)$}

This site is about 100 miles northwest of Moscow. Two 1000-MWe VVER-1000 PWRs are under construction 1,2 to be manufactured at the Atomash plant at Volgodonsk. 24

Units KAl and KA2 (578 SU P) should have been commissioned in ' 78 and ' 80 but neither has been completed (as of late 1981). More likely dates are 
$181 / 82$ and $183 / 84$, and the Five-Year Plan calls for increased capacity in the 1981-85 period, $5,15,16$ which presumably implies finishing these two units.

Expansion of the site to 4000 MWe by adding two additional VVER-1000 PWRs beyond 1985 possibly is planned.

\section{Ignalina (I)}

This site is located at Lake Orukshai in the Lithuanian Republic. ${ }^{7,10}$ It will contain the first of a larger version of the boiling-water, graphitemoderated reactors (LGRs), perhaps a "sectional-lumped" or modular reactor (presumably modular cooling) that may be developed to 2400 -MWe capacity. ${ }^{24}$

The Izhursky manufacturing plant at Leningrad is fabricating equipment for the first unit. 14 This station will provide power for the Baltic Republics where there is a scarcity of local fuels.

The first two units should be commissioned "by the early " 80 s" $^{14}$ and ultimately a four-unit station of 6000 MWe is planned. ${ }^{10}$ The 1981-85 FiveYear Plan calls for commissioning the first sections, $5,15,16$ which perhaps implies units II and I2 by 1985 and units I3 and I4 after that.

15. Balakovo (BA) $(52.04,47.46)$

This site is located in the Volga northeast of Saratov. A 2000-MWe capacity is planned, presumably two 1000-MWe reactors, but there is no indicaticn of the reactor type. Pumped storage is planned as the site will contain "a dam, hydroaccumulator, and nuclear unit." 19 Both units are under construction, ${ }^{19}$ and the Five-Year Plan calls for commissioning, probably of both units, in the 1981-85 period. 15,16

\section{Khmelnitsky (KH) $(49.25,26.59)$}

This site is located in the Western Ukraine and is jointly financed by the USSR (50\%), Poland (25\%), and Hungary and Czechoslovakia (25\% together). Its 4000-MWe capacity is intended to be shared by the contributors in proportion to their investment. Supposedly complete by 1984, the station would be entirely USSR-owned after 2003 when the other countries would receive power on a normal commercial basis. ${ }^{26}$

There is no indication of the reactor type but, assuming four 1000-MWe reactors, it is difficult to see that they could be PWRs with the projected start-up date of 1984. Therefore they are probably LGRs of the Leningrad type. 
The Five-Year Plan calls for commissioning capacity in the 1981-85 period but does not mention completion of the station. 5, 15,16 A more reasonable schedule would give 2000 MWe by 1985 and a further 2000 MWe by perhaps 1990.

17. "Khmelnitsky II" (KHII)

A second jointly-financed station of unknown size, location, or completion date is planned. 26

18. Zaporozhe (Z) $(47.50,35.10)$

This plant is located in the Southern Ukraine on the Dneiper River. Construction is to be expanded in the 1981-85 period ${ }^{16}$ (presumably the Zaporozhyegn Tsimlyansk of Ref. 5).

19. Rostov (RO) $(57.11,39.23)$

This is presumably Rostov located about 100 miles north of Moscow not Rostov-on-Don in the Donets Basis $(47.15,39.45)$. It is to be commissioned in the 1981-85 period. ${ }^{16}$

20. Krymsk (KR)

The Five-Year plan calls for expanded construction in Krymsk (the Crimea) in the $1981-85$ period. ${ }^{16}$

21. Tatar (TA) $(55.42,52.20)$

A station is to be constructed near the industrial centers of Nizhnekamsk and Naberezhniye Cheiny in the Tatar Autonomous Republic. ${ }^{22}$

22. Odessa (0) $(46.30,30.46)$

A reactor system, primarily for district heating, is under construction here. 16,20 It is described as "probably 1000-MWe equivalent, "5 which would correspond to about $3500 \mathrm{MW}$ (thermal) and should be commissioned by 1985. No design details are known.

23. Gorki (G) $(57.36,45.04)$

Construction of two 500 -MWe reactors for district heating has started, ${ }^{27}$ but no technical details nor completion date are given. 


\section{Dimitrovgrad (D) $(53.00,55.00)$}

A $5-W$ pilot plant for local heating has been placed in operation at Dimitrovgrad in the Ulyanov 0blast. It can be disassembled into 20-ton units for transportation and is intended to "supply power and heat" to remote settlements, such as the far north or east. ${ }^{28}$

\section{REFERENCES (USSR)}

1. "World List of Nuclear Power Plants," Nucl. News, 24, 93-94 (February 1981).

2. "Power Reactors 180," Nuc. Eng. Int. Supplement 25, 3-72 (July/August 1980).

3. "The USSR expects to add 4,000-5,000 MW of nuclear generating capacity," Nuc leon ics Week, 20, 7 (December 6, 1979).

4. P. Hann, "Concerns over nuclear power development unwarranted, Soviets assert," Nucleonics Week 20, 5 (December 20, 1979).

5. "The Soviet Union plans to commission new nuclear power plants," Nucleonics Week 20, 6-7 (December 11, 1980).

6. J. Moore, "International progress with liquid-metal fast reactors -USSR," NuC. Eng. Int. 24, 37-49 (July 1979).

7. "Construction Progress -- Reports from world nuclear power station sites -- USSR," Nuc. Eng. Int. 21, 50 (March 1976).

8. "World Digest: USSR -- VVER gets double pressure envelope," Nuc. Eng. Int. 22, 14 (October 1977).

9. "Monitor: World Markets -- a review of existing work and future prospects -- Soviet Union," Nuc. Eng. Int. 23, 21 (October 1978).

10. "USSR -- Bilibino 4 now operating," Nuc. Eng. Int. 22, 14 (February 1977).

11. "The Soviets have put two more nuclear power stations into operation," Nucleon ics Week 21, 5 (March 6, 1980).

12. "The third 1,000-MW graphite-and-water reactor at the Leningrad station," Nucleonics Week 21, il (July 17, 1980).

13. "The USSR has not kept to the schedule for its Leningrad Nuclear Stations," Nucleonics Week 20, 7 (August 30, 1979).

14. "The second 1,000-MW unit at the Kursk nuclear plant has started up," Nucleonics Week 20, 15 (February 1979).

15. "Nows Review: Five Year Plan accelerates nuclear programme," Nuc. Eng. Int. 26, 4 (January 1981). 
16. "Draft Guidelines for 11th Five-Year Plan," Curr. Dig. Sov. Press XXXII, No. $48,1-26,32$ (December 31, 1980).

17. "Soviet Union workers assemblig the second 405-MW PWR unit," Nucleonics Heek, 20, 12 (October 25, 1979).

18. "The Soviet Union expects to have 13,000-13,500 MW of nuclear power capacity," Nucleonics Week 21, 13-14 (July 3, 1980).

19. "Poor Soviet management and supply bottlenecks are blamed for lagging work," Nucleonics Week 21, 9-10 (April 10, 1980).

20. "A 440-MW PWR at Rovno in the Ukraine has been commissioned, "Nucleonics Week 22, 7 (January 8, 1981).

21. "Domestic Affairs: Industry -- Reactor in Operation," Curr. Dig. Sov. Press XXXII, No. 52, 19 (January 28, 1981).

22. "Soviet authorities claim to have finished the first pressure vessel," Nuc leon ics Week 22, 10 (February 26, 1981).

23. J. Moore, "International progress with liquid-metal fast reactors -USSR," Nuc. Eng. Int. 24, 37-49 (July 1979).

24. "A 440-MW PWR at Rovno in the Ukraine has been commissioned," Nucleonics Week 22, 7-8 (January 15, 1981).

25. "A chronic labor shortage is causing problems," Nucleonics Week 21,5 (November 20, 1980).

26. "The USSR, Poland, Hungary and Czechoslovakia will jointly finance construction," Nucleonics Week 20, 12 (April 19, 1979).

27. "Work is apparently going smoothly at the Gorki nuclear plant," Nucleonics Week 21, 7 (September 4, 1980).

28. "The Soviet's first mini-nuclear power plant," Nucleonics Week 21,13 (January 3, 1980).

\section{BULGARIA}

A. Reactor Types and Location

A11 present and currently projected plants are the Soviet VVER-440 PWR type. All are or will be located at Kozloduy (also Kozlodui), which is situated on the Danube in the northeast part of the country (on the BulgariaRomania border). 
1. Operating:

The nominally 440-MWe Kozloduy 1 and 2 reactors commenced operation in December 1974 and December 1975 respectively. ${ }^{1}$ The net output of each is 405 MWe and there are slight differences in design $(6$ coolant loops in No. 1 vs 3 in No. 2). ${ }^{2}$ Both reactors were supplied by the USSR (Atomenergo).

2. Under Construction

Kozloduy 3 and 4 are also nominally 440 MWe with anticipated net outputs of 410 MWe. $^{2}$ The originally scheduled operating dates were 1978 and 1979, respectively, but each has been delayed three years, and now they are expected to be operating in 1981 and 1982.

Construction of a fifth reactor reportedly has begun with a projected start-up date of $1984 .^{3}$ This is a 1000-MWe unit and is presumably a Sovietsupplied PWR. In view of past delays in construction a start-up date of 1987 seems more likely.

B. Other Nuclear Activities

Bulgaria has designed a barge specifically to transport spent fuel from Kozloduy about 250 miles down the Danube. ${ }^{4}$ There is no indication whether the barge is intended to provide complete transportation to the USSR (across the Black Sea and then possibly by river or canal in the USSR), or whether there will be transfer to rail or road, presumably in Romania in the lower reaches of the Danube.

REFERENCES (Bulgaria)

1. "World List of Nuclear Power Plants," Nuclear News 24, 76 (1981).

2. "World List of Nuclear Power Plants," Nucl. Eng. Int. Supplement 25, (July/August 1980).

3. "Construction of a Fifth Unit at Bulgaria's Kozlodui Nuclear Station," Nucleonics Week 21, 11 (July 17, 1980).

4. "Bulgaria has claimed development at world's first barge designed to haul spent nuclear fuel," Nucleonics Week 21, 2 (June 19, 1980). 


\section{A. Reactor Types and Location}

With the exception of the first reactor constructed, all czech plants now in operation and anticipated are of the Soviet VVER PWR type.

\section{Operating}

The first reactor, which is still operating at Jaslovsk Bohunice (Bohunice 1A), is 104 MWe, heavy-water moderated, uranium-metal fueled, pressurized-CO $\mathrm{CO}_{2}$-cooled. ${ }^{1,2}$ This reactor was of Czech design and construction with an unknown degree of Soviet assistance. It, started up in December 1972 after about 15 years under construction, which may indicate Soviet reluctance regarding this independent venture. It has been reported ${ }^{3}$ that the Czech's used "their own heavy water and uranium," but this seems unlikely as there is no other report of heavy-water production or fuel-element fabrication in Czechos lovakia.

This reactor was the scene of a little-publicized accident in January 1976 that killed two persons (the only such power reactor accident world wide). This appears to have occurred during on-line (at power) refueling. ${ }^{3}$ This incident appears to have terminated this line of development.

The only other reactors currently operating are two VVER-440 reactors also at Bohunice. These reactors (2A, 2B) are each 410 MWe and commenced operation in December 1978 and March 1980.

2. Under Construction

Two additional VVER-440 units (each 413 . Me) are under construction at Bohunice ( 3 and 4) and scheduled for start-up in 1982 and ' 83 . More likely dates (judged by the delay in No. 2B) are 1984 and 1985. 2,3

Four VVER-440 reactors are also under construction at Dukovany (Nos. 1, 2, 3, and 4) each of 413 MWe. Scheduled start-up dates are 1983, 184, and -85. ${ }^{2,3}$ An additional two VVER -440 reactors are under construction at Leviece (Nos. 1 and 2) with scheduled start-up dates of 1987 and $188 .{ }^{3}$

Start-up of a 1000-MWe unit in 1985 has been reported ${ }^{4}$ at Malovice in southern Chekhiya (Bohemia). 5 
It is not known which, if any, of these plants will be built in Czechoslovakia; the first of these latter (for Hungary) was completed in $1980 .^{6}$

All of the start-up dates given above for Dukovany, Leviece, and Malovice are likely to be optimistic by one to two years.

3. Other Reactor Sites and Projected Capacities

In addition to the Bohunice, Dukovany, Leviece, and Malovice sites mentioned above, sites have been mentioned at Mochovce (Slovakia) ${ }^{5}$ and unnamed locations in south and central Bohemia, south Moravia, and central Slovakia. $^{3}$ The central Slovakia site may be Mochovce; the south Bohemia site is assumed to be Malovice; and the site at Leviece is probably intended to contain a total of four VVER-440 units. ${ }^{3}$

The overall capacity that official projections state will be achieved by 1985 is $3500 \mathrm{MWe}^{4}$ and the planned capacity by 1990 is $10000 \mathrm{MWe}^{7}$

No specific megawatt power goal is given for the year 2000, but a target of $50 \%$ of electricity generated by nuclear means has been quoted. 8

B. Reactor Manufacturing

\section{Overview}

The manufacture of VVER 440s for the comecon countries, for the Soviet Union itself, and for export has apparently been taken over by Czechoslovakia, principally at the SKODA works at Plzen. 9 The first VVER-440 reactor for Hungary was completed in $1980,{ }^{6}$ and the plant will be making 1000-MWe units by $1990.8,10$ Presumably, as in the USSR, the manufacture of the smaller units will be reduced or even phased-out as the capability for manufacturing the larger reactors is developed.

\section{Component Manufacture}

In addition to the manufacture of components and reactor assembly at the main establishment at Plzen (SKODA works), there is also manufacture of turbines, electric generators, steam generators, separators, steam heaters, valves, piping and other components at Plzen and elsewhere.

In addition to Plzen, the SIGMA works at 0lomauc, the VZKG works at Ostrava, SONP Metallurgical works at Kladro, the VTZ Rolling Mills and Iron 
Works in Choniutov, and the Slovak Engineering works at Timace are involved.

\section{Capacity}

The stated capacity of Plzen varies. It was initially reported (1977 and '78) that 10 units, each 500 MWe, would be produced annually; ${ }^{8,11}$ these presumably actually would be 10, 440-MWe VVER units. A figure of 4 to 5 VVER-440 units has also been reported (1978), ${ }^{12}$ and later statements are made of 10 units between 1976-80 (1979), 13 and 10 to 13 units during 1981-85 (1980). ${ }^{4}$ Bearing in mind the over-optimism associated with all plans when first announced, and perhaps particularly Five-Year Plans, the figure of 10 annually probably can be discounted completely. The initial manufacturing rate most likely will lie at the lower end of 2 to $21 / 2$ per year, with a rate of 4 to 5 being achieved perhaps after 1985.

These figures are for VVER-440 units. The manufacturing rate for VVER1000 units would be expected to exceed half these figures at least after some experience is gained. A guess would be 1 to 2 annually between 1985-90 and 2 to 4 annually after 1990.

\section{Finances}

The Comecon countries and Yugoslavia have supplied approximately $50 \%$ of the investments to build up czech nuclear manufacturing capacity. ${ }^{12}$ Presumabiy this investment is repaid in $k$ ind by delivery of reactors and components. It is interesting to note that Czechoslovakia is spending "hard currency" on materials and technology, and that it expects future buyers to pay part of the costs also in hard currency. 14

\section{Fast Breeders}

In addition to the PWR effort, Czechoslovakia is also contributing to the fast-breeder program by the design of a prototype steam generator tested in the USSR BOR 60 reactor. 8,10

\section{Other Nuclear Energy Activities}

1. Joint Financing of USSR Plant

The USSR, Poland, Hungary, and Czechoslovakia are jointly funding the construction of a 4000 -Mwe nuclear plant at Khmelnitsky in the Ukraine. A 
second jointly financed station of similar size is planned. Repayment of the investment will be by delivery of electricity (in proportion to the investment about 12.5\%) from 1984 (completion date) to 2003. After 2003 the station would be wholly owned by the USSR. ${ }^{15}$

\section{Process Heat Reactors}

Soviet design 500-MW (presumably thermal megawatts) reactors are being considered for industrial use in Bratislava, Brno, 0strava, and Prague. ${ }^{3}$ This is the only mention of industrial heat reactors in the Soviet Bloc although reactors for district heating are being constructed in the USSR (see USSR section).

3. Mining and Milling

A uranium-ore processing plant, at least partially under Czechoslovak control, has been opened in North Bohemia at Strazi pod Ralsken (1979). 14 it is "in close cooperation with the Soviet Union" but apparently represents a partial return of control of Czech ores to national use. Because of the displacement of existing villages and railroads, it is more cost effective to

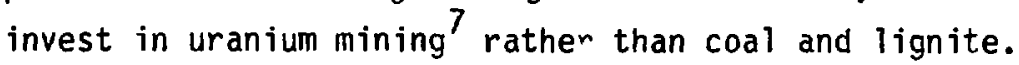

\section{Reprocessing}

In 1978 it was stated that there are plans for the "construction of a reprocessing plant to be built by Czechoslovakia, the German Democratic Republic and Poland." 8 There is no indication of the actual location of the plant nor by whom, and under what controls, such a plant would be operated.

\section{REFERENCES (Czechos lovakia)}

1. "World List of Nuclear Power Plants," Nucleonics News 24. 77 (February 1981).

2. "World List of Nuclear Power Plants," Nucleonics Eng. Int. Supplement $\underline{25}$, 3 and 65 (JuTy/August 1980).

3. A. Keilberth and R. Smith, "First Nuclear Power Fatal Accident Appears to Have Been at Czech Plant," Nucleonics Week, 20, 3 (February 1, 1979)."

4. "Nuclear plants will generate more than a third of Czechoslovakia's electricity," Nucleonics Week 21, 6 (July, 31, 1980). 
5. "Large atomic power plants going up," Cur. Dig. Sov. Press, $x \times X I I$, No. 30, 15 (August 27, 1980).

6. "Czechoslovakia has completed building its first Soviet-designed 440-MW PWR," Nucleonics Week 21, 16 (March 13, 1980).

7. "Czech premier calls for more nuclear power," Nucl. Eng. Int. 24, 9 (April 1979).

8. "The metallurgical and engineering industries of Czechoslovakia are to get a greater share in nuclear engineering within the CMEA," Nucl. Eng. Int. 23, 11 (October 1978).

9. "The Soviet Union expects to have 13,000-13,500 MW of Nuclear Power Capacity," Nucleonics Week, 21, 13 (July 3, 1980).

10. "Czechoslovakia - Heading for self-sufficiency," Nucl. Eng. Int. 22, 7 (October 1977).

11. "Czechoslovakia - On way to becoming nuclear engineering power within the CMEA," Nuc 1. Eng. Int. 22, 8-9 (September 1977).

12. "Boost to nuclear industry to continue in 1978," Nucl. Eng. Int. 23, 8 (February 1978).

13. "Czech premier calls for more nuclear power," Nucleonics Eng. Int. 22, 9 (April 1979).

14. "Uranium plant opens rich vistas for Comecon," Nucl. Eng. Int. 24, 6 (September 1979).

15. "The USR, Poland, Hungary and Czechoslovakia will jointly finance construction," Nucleonics Week 20, 12 (April 19, 1979).

IV. THE GERMAN DEMOCRATIC REPUBLIC (EAST GERMANY)

\section{A. Reactor Types and Location}

All reactors are PWRS of USSR design.

The first reactor (Rheinsberg 1, Granesee region) was a 70-MWle reactor started up in 1966. ${ }^{1,2}$ There were apparently problems with this first system as it was originally intended for operation in 1960.1

There are three other operating reactors all VVER-440 types and all located at Lubmin (Greitswald region) in the Nord plant (Nord 1.1, 1.2, and 2.1). Nord 1.1 came on line one year earlier than projected initially, Nord 1.2 was on time, and Nord 2.1 was delayed perhaps six months. The Nord 2.2 start-up date has slipped from 1978 to ' 81. 
The two VVER-440 units at Magdeburg are not in operation although the initially quoted start-up was 1980.

Steam separators for Nord were built in Czechoslovakia. 3

A third reactor site at Stendal has been mentioned once and is probably for longer term development. 4 This reference also mentions delays in the nuclear program and that nuclear power will now contribute 12 to $14 \%$ of total electricity by 1985 .

B. Other Nuclear Activities

The GDR intends to store radioactive waste in a salt mine at Bartenselben (1977), ${ }^{5}$ whin lies close to the West German border at Helmstadt (35 km east of Wolfburg). No other information is available.

A processing plant constructed jointly with Poland and Czechoslovakia was discussed $(1978),{ }^{6}$ but further progress is not indicated.

\section{REFERENCES (GDR)}

1. "World List of Nuclear Power Plants," Nucl. News 24, 78 (February 1981).

2. "Progress Schedules," Nuc. Eng. Int. Supplement 25, 64 (July/August 1980).

3. "Czechoslovakia: On way to becoming nuclear engineering power within the CMEA," Nuc. Eng. Int. 22, 9 (1977).

4. L. Colitt, "N-power setback in E. Germany," Financial Times (London) p. 2 (Apri) 22, 1981).

5. "East Germany plans for salt mine storage," Nuc. Eng. Int. 22, 12 (January 1977).

6. "The metallurgical and engineering industries of Czechoslovakia are to get a greater share in nuclear engineering within the CMEA," Nuc. Eng. Int. 23, 11, (October 1978).

V. HUNGARY

A. Reactor Types and Location

All reactors under construction and projected are Soviet PWR systems, both $440 \mathrm{MWe}^{\mathrm{l}, 2}$ and $1000 \mathrm{MWe}$. 
The only identified site is Paks, situated on the Danube south of Budapest. It will contain four VVER -440 reactors all of which will be built by Czechoslovakia. The first Hungarian unit was also the first completed by the Czechs. Three VVER-1000 units will be brought on line at Paks in the 1987-90 period, giving Paks a total capacity of 4760 MWe. For comparison, the entire capacity (all non-nuclear) in 1979 was $4100 \mathrm{MWe}^{3}$ Who wili build the 1000MWe units is not known.

Hungary states that it expects a total nuclear capacity of 10000 to 12000 MWe by $2000 .^{3}$ The time scale for these plans seems over-optimistic. The Paks 1 and 2 units, (440 MWe) are not yet in operation, and the projected start-up dates have receded from 1980 (for both) to ' 82 and ' 83 respectively. The Paks 3 and 4 units (also 440 MWe) have anticipated start-up dates of 1984 and '85. Start-up dates of 185 and ' 86 seem more reasonable.

The projected installation of three 1000-MWe units at Paks in the 1987-90 period seems very optimistic. Installation over the 1989-95 period seems more reasonable.

B. Other Nuclear Activities

Hungary is contributing finances to the construction of the 4000-MWe Khmelnitsky plant in the Ukraine together with the USSR, Poland, and Czechoslovakia. ${ }^{4}$ Hungary will receive repayment in electricity (in proportion to the contribution, about 12.5\%) over the period from completion in 1984 until 2003. Following 2003 the plant will be entirely USSR owred.

\section{REFERENCES (HUNGARY)}

1. "World List of Nuclear Power Plants," Nucl. News 24, 79 (February 1981).

2. "Power Reactors '80," Nuc. Eng. Int. Supplement 25, 67 and 496 (Ju?y/ August 1980).

3. "Czechorlovakia has completed building its first Soviet-designed 440-MW PWR," Nucleonics Week 21, 16 (March 13, 1980).

4. "The USSR, Poland, Hungary and Czechoslovakia will jointly finance construction," Nucleonics Week 20, 12 (April 19, 1979). 
VI. POLAND

\section{A. Reactor Types and Location}

In the mid-70s government plans called for a major use of nuclear power by 2000 and the use of nuclear heat for industrial processes was also considered. ' At the same time the site of the first station, Zarnowiec Lake near Gdonsk in northern poland, was selected and che projection was that it would be coupled with a pumped-storage scheme of 680-MW capacity. 1 The reactor type chosen was the VVER-440 with Poland supplying heat exchangers, controls, and turbogenerators. The original target was a 1983 start-up.

The first site remains, with two VVER-440 units under construction, further units intended, and a "connection with a non-nuclear plant, "2 which could refer to pumped storage. The projected start-up dates for units 1 and 2 are given variously as 1985 and 186 and $1986 / 87.3,4$ In view of the fact that "construction will start this year" $(1981)^{2}$ and construction is expected to take six years, ${ }^{2}$ more probable dates are $1987 / 88$. This slow tempo has been criticized officially. 5

A second site, Kujawy, in Central Poland has been selected to be built after $1985 .{ }^{2}$ The capacity is unknown.

\section{B. Projected Capacity}

Early statements (1976) talked of $13 \%$ of the electricity generation being nuclear by 1990 and $40 \%$ by $2000 .^{1}$ A slightly later statement (1977) gave a projection of 8500 MWe by $1990 .^{6}$ These statements are probabiy consistent with each other.

A recent statement (January 1981) ${ }^{2}$ still calls for 20000 to 23000 Mwe installed capacity by 2000 , but that target appears unreasorably high in view of Poland's late start, its economic problems, and its present unpopulari; stance with the USSR, Czechoslovakia and East Germany.

Early plans discussed siting at the Masurian Lakes in northern east Poland near the USSR border. ${ }^{2}$ 
C. Other Nuclear Activities

Together with the USSR, Hungary, and Czechoslovakia, Poland is firancing the construction of the 4000-MWe Khelmitzkiy plant in the Ukraine. The payment would be as 25\% of the output from start-up in 1984 until 2003, when the plant would be entirely owned by the USSR. ${ }^{7}$

Joint construction of a processing plant with the GDR and Czechoslovakia has been discussed (1978), 8 but there is no indication that this has gone forward.

\section{REFERENCES (POLAND)}

1. "Poland's nuclear plans," Nuc. Eng. Int. 21, 10-(January 1976).

2. "Poland will start construction of its first nuclear station this year," Nucleonics Week 22, 5 (January 29, 1981).

3. "World List of Nuclear Power Plants," Nuc 1. News 24, 82 (February 1981).

4. "Power Reactors '80 -- Section 1. General Information," Nuc. Eng. Int. Supplement 25, 22-23 (July/August 1980).

5. "Poland's Commurist Party Paper 'Trybuna Ludu' criticized," Nucleonics Week 21, 6 (January 3, 1980).

6. "Station construction to start in 1979," Nuc. Eng. Int. $\underline{22}, 11$ (February 1977).

7. "The USSR, Poland, Hungary and Czech, will jointly finance construction," Nuc leonics Week 20, 12 (April 19, 1979).

8. "Czechoslovakia - The metallurgical and engineering industries of Czechoslovakia are to get a greater share in nuclear engineering with in the CMEA," Nuc. Eng. Int. 23, 11 (October 1978).

\section{ROMANIA}

Apart from a desultory relationship with the USSR that has led to the purchase of one VVER-440 unit, Romania has devoted herself entirely to attempting to introduce the Canadian CANDU heavy-water reactor technology. These reactors are to be fueled (it appears) with Romanian natural uranium. 
1. Operating

One VVER-440 unit, being constructed at 01t, was apparently supplied by the USSR. Originally scheduled to be in operation in 1980 it is now projected for 1983. 1,2 This appears to be the only reactor of this type that Romania intends to construct.

A second standard 600-MWe CANDU reactor, purchased from Canada, is under construction at Cernavoda with a projected start-up of 1987. Romania has indicated that as many as .12 to 16 CANDU units could be in operation by 2000 , but the negotiations with Canada (and other countries to some extent) have been long anu inmplicated.

\section{Finances}

There seems to be no doubt of the Romanian intent to build many heavywater reactors, either obtained from Canada or elsewhere, but there are two very important factors. First and perhaps most important, Romania's lack of hard currency has led to her insistence upon some form of "contracting" arrangement that allows the purchases to be paid for by Romanian exports such as wine, tractors, clothing, furniture, and machinery. 3,4 This presents considerable difficulty for the Canadian government and a similar proposal to France (Framatome) was rejected. ${ }^{4}$ Secondly, and also very important, is Romania's insistence upon technology transfer, apparently aimed at independent production of reactors at the earliest opportunity. ${ }^{5,6}$ These technology requests are apparently well beyond what most manufacturers regard as reasonable.

As a result, although negotiations have been in progress in some form since 1967,7 there is still considerable uncertainty in the eventual outcome. ${ }^{8}$ The Canadian government is providing considerable support in financial matters ${ }^{9}$ but the situation remains as one firm order and one letter of intent.

Heavy water would be supplied (at least initially) by Cánada. ${ }^{5}$ Fuel presumably would be supplied eventually by Romania although the initial charge would be purchased. 
B. Other Nuclear Activities

Romania was one of the first signatories of the Nuclear Nonproliferation Treaty (NPT) and has long been involved in IAEA safeguards. 7

\section{REFERENCES (ROMANIA)}

1. "Power Reactors ' $80, "$ Nuc. Eng. Int. Supplement 25, 22-23 (July/August 1980).

2. "World List of Nuclear Power Plants," Nucl. News 24, 82 (February 1981).

3. "Romanian wine and tractors for CANDUS?," Nucleonics Week 21, 10 (September 11, 1980).

4. "Romanian agreement on second CANDU purchase put in doubt by ambassador," Nuc leonics week 21, 3 (October 2, 1980).

5. "AECL completes deal with Romanians," Nuc. Eng. Int. 23, 3, (November 1978).

6. "Romanian nuclear pact nears fruition," Nuc. Eng. Int. 23, 12 (May 1978).

7. "Romania plans to start building CANDUS next year," Nuc. Eng. Int. 22, 28-29 (June 1977).

8. "The Canadian Nuclear Industry is Confidently Talking of 6-7 CANDU EXports," Nucleonics Week 21, 10 (October 9, 1980).

9. "Canada and Romania have concluded the financing agreement," Nucleonics Week 20, 12 (May 3, 1979). 